This document was prepared in conjunction with work accomplished under Contract No. DE-AC09-96SR18500 with the U. S. Department of Energy.

\title{
DISCLAIMER
}

This report was prepared as an account of work sponsored by an agency of the United States Government. Neither the United States Government nor any agency thereof, nor any of their employees, nor any of their contractors, subcontractors or their employees, makes any warranty, express or implied, or assumes any legal liability or responsibility for the accuracy, completeness, or any third party's use or the results of such use of any information, apparatus, product, or process disclosed, or represents that its use would not infringe privately owned rights. Reference herein to any specific commercial product, process, or service by trade name, trademark, manufacturer, or otherwise, does not necessarily constitute or imply its endorsement, recommendation, or favoring by the United States Government or any agency thereof or its contractors or subcontractors. The views and opinions of authors expressed herein do not necessarily state or reflect those of the United States Government or any agency thereof. 


\section{“Low-Li 2 O" Frits: Selecting Glasses that Support the Melt Rate Studies and Challenge the Current Durability Model}

D.K. Peeler

T.B. Edwards

July 2005

Immobilization Technology Section

Savannah River National Laboratory Aiken, SC 29808 


\section{DISCLAIMER}

This report was prepared by Westinghouse Savannah River Company (WSRC) for the United States Department of Energy under Contract No. DE-AC09-96SR18500 and is an account of work performed under that contract. Neither the United States Department of Energy, nor WSRC, nor any of their employees makes any warranty, expressed or implied, or assumes any legal liability or responsibility for the accuracy, completeness, or usefulness, of any information, apparatus, or product or process disclosed herein or represents that its use will not infringe privately owned rights. Reference herein to any specific commercial product, process, or service by trademark, name, manufacturer or otherwise does not necessarily constitute or imply endorsement, recommendation, or favoring of same by WSRC or by the United States Government or any agency thereof. The views and opinions of the authors expressed herein do not necessarily state or reflect those of the United States Government or any agency thereof.

Printed in the United States of America

Prepared For

U.S. Department of Energy 
Key Words: durability, melt rate, sludge batch

Retention: Permanent

\section{“Low-Li2 O" Frits: \\ Selecting Glasses that Support the Melt Rate Studies and Challenge the Current Durability Model}

D.K. Peeler

T.B. Edwards

July 2005

Immobilization Technology Section Savannah River National Laboratory Aiken, SC 29808

Prepared for the U.S. Department of Energy Under Contract Number DEAC09-96SR18500

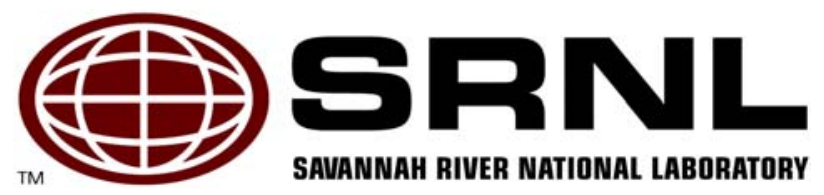




\section{REVIEWS AND APPROVALS}

\section{AUTHORS:}

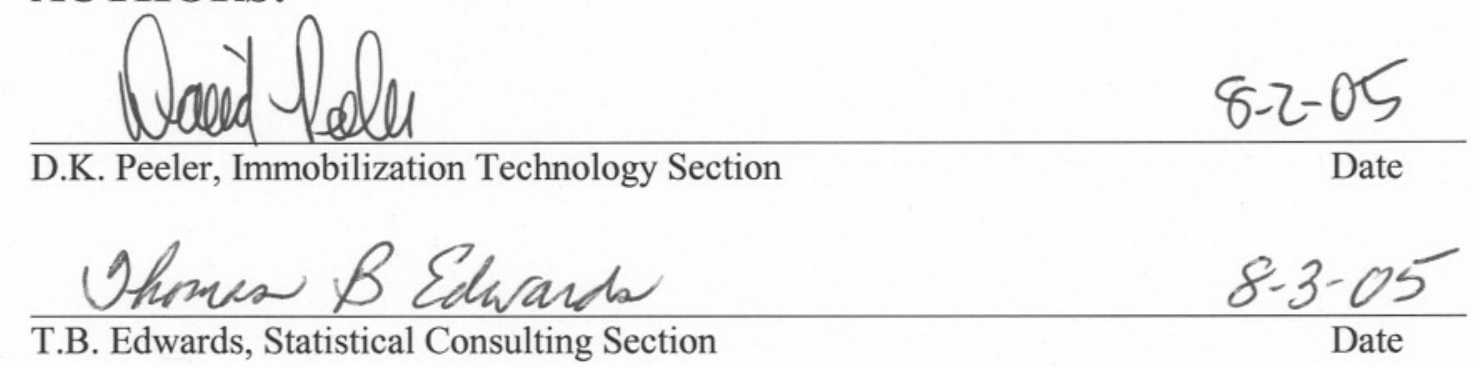

\section{TECHNICAL REVIEWER:}

Comne C. Herman $8.2-05$

\section{APPROVERS:}

EN toetzahuter

E.W. Holtzscheifer, Manager, Immobilization Technology Section

Shaven 8 Mane

S.L. Marra, Manager, Glass Formulation \& Process Development
$8-4-05$

Date

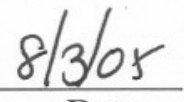


WSRC-TR-2005-00306

Revision 0

\section{EXECUTIVE SUMMARY}

During the progressive development of the cold cap model (as it applies to a potential melt rate predictive tool), the formation of an Al-Li-silicate phase was identified as an intermediate reaction phase that could possibly hinder melt rate for SB4. To test this theory, six glasses were designed (using Frit 320's composition as the baseline) to maintain a constant 20 wt\% sum of alkali content (in frit) by varying $\mathrm{Na}_{2} \mathrm{O}$ to $\mathrm{Li}_{2} \mathrm{O}$ ratios. The $\mathrm{Li}_{2} \mathrm{O}$ concentration ranged from 8 wt $\%$ down to $0 \%$ in either $2 \%$ or $1 \%$ increments with the differences being accounted for by an increase in $\mathrm{Na}_{2} \mathrm{O}$ concentration. Although the primary objective of the "lower $\mathrm{Li}_{2} \mathrm{O}$ " frits was to evaluate the potential for melt rate improvements, assessments of durability (as measured by the Product Consistency Test (PCT)) were also performed. The results suggest that durable glasses can be produced with these "lower $\mathrm{Li}_{2} \mathrm{O}$ " frits should it be necessary to pursue this option for improving melt rate.

In addition to the series of glasses to support melt rate assessments, a series of frits were also developed to challenge the current durability model based on the limits proposed by Edwards et al. (2004). Although the "new" limits allow access into compositional regions of interest (i.e., higher alkali systems) which can improve melt rate and/or waste loading, there may still be "additional" conservatism. In this report, two series of glasses were developed to challenge the "new" durability limits for the SB4 system. In the first series, the total alkali of the Frit 320based glasses (designed to support the melt rate program) was increased from $20 \mathrm{wt} \%$ to $21 \mathrm{wt} \%$ (in the frit), but the series also evaluated the possible impact of various $\mathrm{Na}_{2} \mathrm{O}$ and $\mathrm{Li}_{2} \mathrm{O}$ mass ratio differences. The second series pushed the alkali limit in the frit even further with frits containing either 22 or $24 \mathrm{wt} \%$ total alkali as well as various $\mathrm{Na}_{2} \mathrm{O}$ and $\mathrm{Li}_{2} \mathrm{O}$ mass ratios.

The results of the PCT evaluation indicated that all of the "higher alkali" glasses are acceptable as defined by their NL [B]'s as compared to the Environmental Assessment (EA) glass (with a $16.695 \mathrm{~g} / \mathrm{L} \mathrm{NL}$ [B]) - regardless of the compositional view (measured or target) or thermal heat treatment (quenched versus centerline canister cooled). The least durable glass (based on NL [B] and target compositions) was Low-Li-7 (quenched) with a NL [B] of $1.11 \mathrm{~g} / \mathrm{L}$. With the measured PCT responses being acceptable (i.e., all $<1.11 \mathrm{~g} / \mathrm{L}$ ), the results suggest additional conservatism exists within the current durability model even with the "proposed" limits. More specifically, the "proposed" limits still appear to restrict access to compositional regions of interest (higher alkali glasses) even though their measured PCT responses are acceptable. 


\section{TABLE OF CONTENTS}

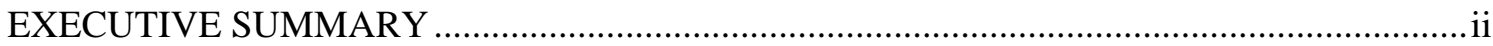

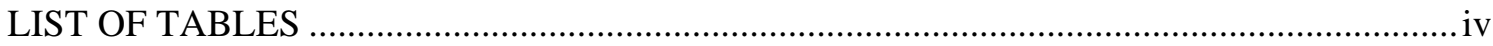

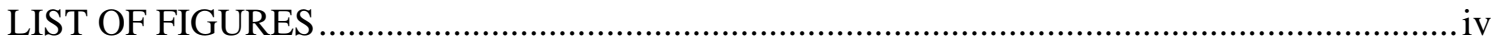

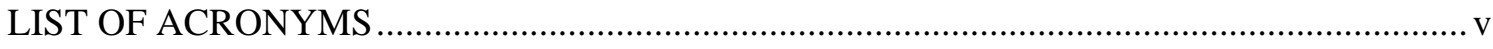

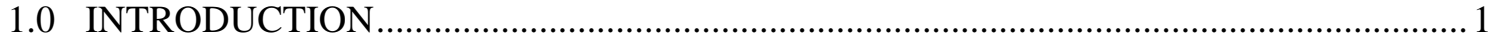

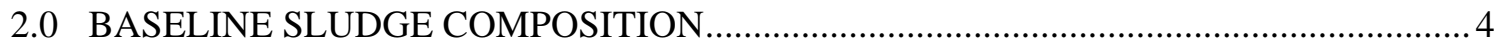

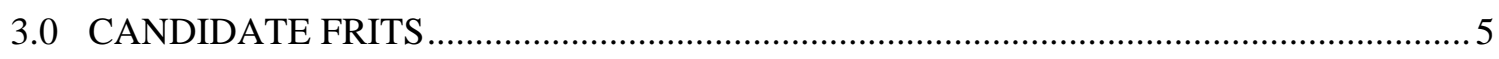

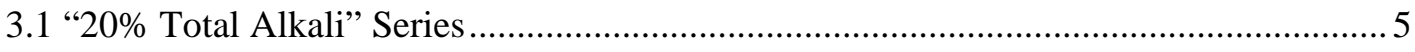

3.2 Challenge to "Proposed” Durability Limits .................................................................... 5

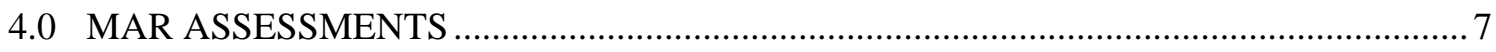

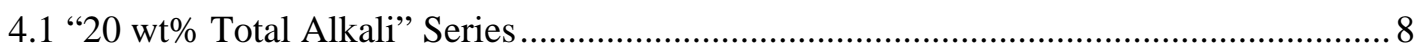

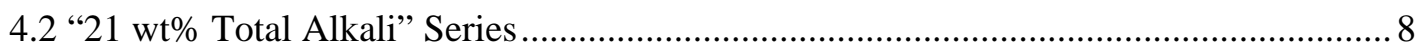

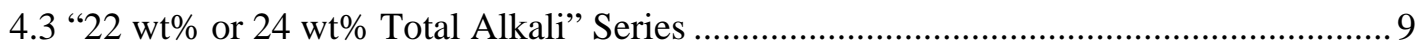

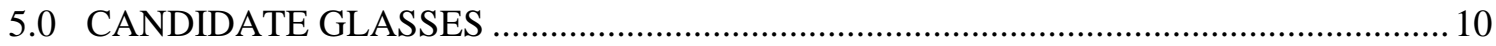

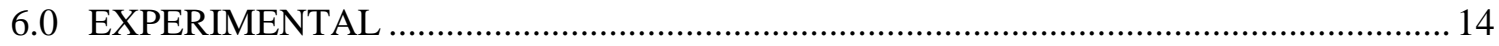

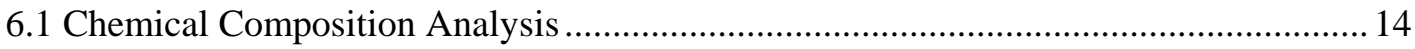

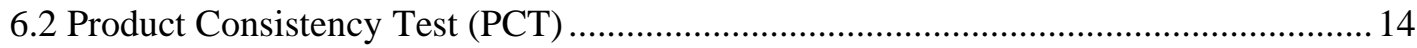

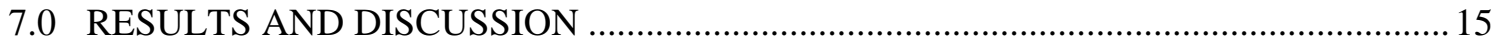

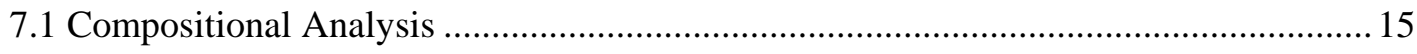

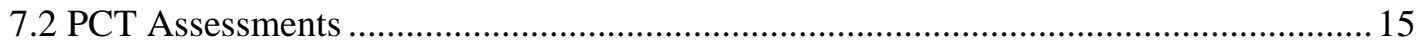

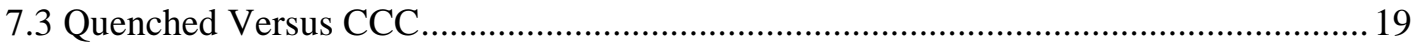

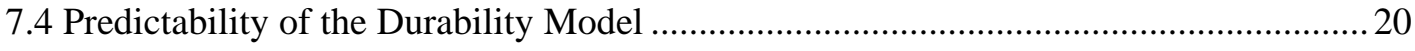

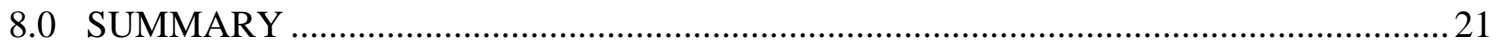

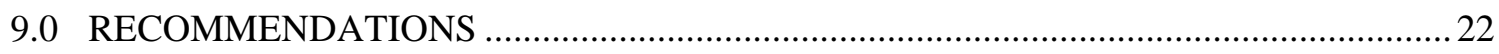

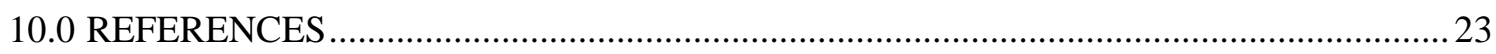

APPENDIX Target Versus Measured Compositions and \% Relative Difference.......................26 


\section{LIST OF TABLES}

Table 2.1 Nominal SB4 Composition Used to Support Testing (from Lilliston 2005)............... 4

Table 3.1 Frit 320 and the "Low $\mathrm{Li}_{2} \mathrm{O}$ ” Based Frit Compositions (wt\%)................................... 5

Table 3.2 Candidate Frits Based on a 21 wt\% Total Alkali Content........................................... 6

Table 3.3 Candidate Frits Based on a 22 or 24 wt\% Total Alkali Content ................................ 6

Table 4.1 MAR Based Projected Operating Windows ..........................................................

Table 5.1 “20 wt\% Total Alkali” Series Target Glass Compositions.........................................11

Table 5.2 “21 wt\% Total Alkali” Series Target Glass Compositions........................................ 12

Table 5.3 “21 wt\% Alkali” Series Target Glass Compositions ................................................ 13

Table 7-1 Normalized PCT Response for the Study Glasses (g/L) (normalized based on

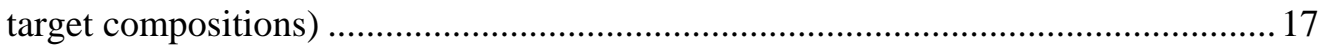

Table 7-2 Normalized PCT Response for the Study Glasses (g/L) (normalized based on

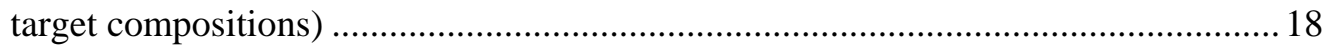

\section{LIST OF FIGURES}

Figure 7-3 Quenched Versus ccc log [B (ppm)] (based on target compositions) ....................... 19

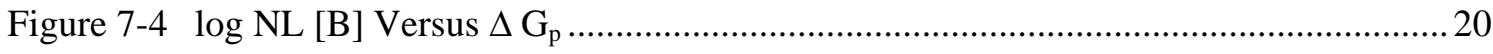




\section{LIST OF ACRONYMS}

$\begin{array}{ll}\text { ARM } & \text { Approved Reference Material } \\ \text { ASTM } & \text { American Society for Testing and Materials } \\ \text { cCC } & \text { centerline canister cooled } \\ \text { DOE } & \text { Department of Energy } \\ \text { DWPF } & \text { Defense Waste Processing Facility } \\ \text { EA } & \text { Environmental Assessment } \\ \Delta \text { GP } & \text { preliminary glass dissolution estimator } \\ \text { ICP } & \text { inductively coupled plasma } \\ \text { MAR } & \text { Measurement Acceptability Region } \\ \text { MRF } & \text { melt rate furnace } \\ \text { NL [B] } & \text { normalized boron release (in g/L) } \\ \text { PCCS } & \text { Product Composition Control System } \\ \text { PCT } & \text { Product Consistency Test } \\ \text { Q } & \text { quenched } \\ \text { REDOX } & \text { REDuction/Oxidation } \\ \text { SB } & \text { sludge batch } \\ \text { SME } & \text { Slurry Mix Evaporator } \\ \text { SRAT } & \text { Sludge Receipt and Adjustment Tank } \\ \text { SMRF } & \text { slurry fed melt rate furnace } \\ \text { SRNL } & \text { Savannah River National Laboratory } \\ \text { SRNL-ML } & \text { Savannah River National Laboratory - Mobile Laboratory } \\ \text { TL } & \text { liquidus temperature } \\ \eta & \text { viscosity } \\ \text { WAPS } & \text { Waste Acceptance Product Specifications } \\ \text { WL } & \text { waste loading } \\ & \end{array}$


WSRC-TR-2005-00306

Revision 0

\subsection{INTRODUCTION}

In support of the Department of Energy's (DOE's) accelerated clean-up mission, the Savannah River National Laboratory (SRNL) has focused on increasing both waste loading (WL) and melt rate which ultimately play a major role in defining waste throughput for the Defense Waste Processing Facility (DWPF). With respect to melt rate, the general trend has been to increase the total alkali content of the glass by using a high-alkali based frit, a less washed sludge, or a combination of the two. Of particular interest has been the concept of a " $\mathrm{Na}_{2} \mathrm{O}$ sliding scale", which has been used to compensate or balance the frit composition with the washing scenario to produce a glass meeting both process and product performance specifications. This approach was very successful as DWPF transitioned from an "over-washed" sludge batch 2 (SB2) to a "less washed" sludge batch 3 (SB3) which, when coupled with a specifically designed frit, improved waste throughput (higher targeted WLs and enhanced melt rates) dramatically.

The strategy for identifying or developing frits for a specific sludge batch is initially based on assessments using predictive models that govern the process control strategy for DWPF. Although candidate frit compositions are identified which satisfy process and product performance requirements over a projected WL range of interest, the paper study assessment does not evaluate melter performance issues related to melt rate and/or waste throughput. Therefore, experimental assessments of melt rate are required to ensure that a specific frit/waste combination that appears attractive on paper (in terms of projected operating windows) does not result in a difficult feed to process through the DWPF.

Over the past few years, the experimental melt rate program has been used as the final screening tool from which recommendations regarding the selection of a specific frit and targeted WL are made to DWPF. The primary experimental melt rate tools currently being used include cruciblescale tests (Stone and Josephs 2001), the dry-fed melt rate furnace (MRF) (Lorier et al. 2002, Lorier and Smith 2004), and the slurry-fed melt rate furnace (SMRF) (Smith et al. (2003), Smith et al. (2004)). Although very effective in terms of ranking various flowsheet options (e.g., different frit compositions or various sludge washing strategies) with respect to melt rate, the experimental melt rate program is both time consuming and labor intensive. Therefore, development of a melt rate model to guide frit development efforts and lessen the dependency on the experimental program would be highly desirable. If successful, such a model would benefit the overall program considerably by allowing more resources to be put on the evaluation of primary flowsheet options.

Choi (2000) describes a 4-stage cold cap model which has been used primarily to assess off-gas flammability issues for DWPF. Recent efforts have been made to extend the utility of this model to assess or rank relative melt rates for various DWPF flowsheet options (Choi et al. 2005). Initial assessments were made to rank or make pair-wise comparisons regarding the impact of frit composition, sludge washing, targeted reduction / oxidation (REDOX expressed as $\mathrm{Fe}^{+2} / \mathrm{Fe}^{\text {total }}$ ), and acid addition strategy on melt rate. Based on the success of those comparisons, assessments associated with the impacts of waste loading on melt rate and/or waste throughput for specific systems were made as well as evaluations regarding the impact of alkali addition sources on melt rate. During the progressive development of the cold cap model (as it applies to a potential melt rate predictive tool), the formation of an $\mathrm{Al}$-Li-silicate phase was identified as an intermediate reaction phase that could possibly hinder melt rate for Sludge Batch 4 (SB4). If true, one could potentially adjust the frit composition (given it is the only source of $\mathrm{Li}$ in the glass system) to minimize or eliminate the formation of this Li-based phase and thus potentially enhance melt rate. To test this theory, a series of "lower $\mathrm{Li}_{2} \mathrm{O}$ " based frits was designed using Frit 320's composition as the baseline (see Section 3.0 for more details). These "lower $\mathrm{Li}_{2} \mathrm{O}$ " based frits were then used to assess melt rate with SB4. Although the primary objective of the "lower $\mathrm{Li}_{2} \mathrm{O}$ " frits was to 
evaluate the potential for melt rate improvements, assessments of durability (as measured by the Product Consistency Test (PCT)) were also performed and are documented in this report. The underlying objective was to provide a preliminary assessment of durability assuming melt rate results suggested that this compositional trend be pursued.

In addition to the series of glasses to support melt rate assessments, frits were also developed to challenge the current durability model based on the limits proposed by Edwards et al. (2004). Previous studies (Peeler and Edwards 2002; Peeler et al. 2004a) have indicated that as higher alkali glass systems are pursued, a transition can occur in which predictions of durability and/or low viscosity begin limiting upper waste loadings rather than predictions of liquidus temperature - the limiting property for current (Frit 418/SB3) and previous DWPF sludge batch processing. Peeler et al. (2001), Cozzi et al. (2003), and Peeler et al. (2004b) have suggested that the current durability model can lead to conservative decisions during the Slurry Mix Evaporator (SME) acceptability process. ${ }^{1}$ More specifically, the model (using its original limits) has restricted access to glass composition regions that could potentially enhance melt rate, $\mathrm{WL}$, or waste throughput by classifying a specific glass composition as "unacceptable" whose experimentally determined durability (as defined by the PCT (ASTM 2002)) is "acceptable" relative to the Environmental Assessment (EA) glass (Jantzen et al. 1993). For example, Peeler et al. (2001) found that the Frit 304 - SB2 system was classified as unacceptable (based on model predictions of durability), but when durability was experimentally determined, the results were well below the acceptance limits (e.g., $1.07 \mathrm{~g} / \mathrm{L}$ compared to $16.695 \mathrm{~g} / \mathrm{L}$ reported for EA). More recent results (Peeler et al. 2004b) assessed the potential use of Frit 320 with SB3. As with the Frit 304 - SB2 system, the high-alkali content of Frit 320 when coupled with SB3 resulted in predictions of durability restricting its potential recommendation. Experimental determination of durability for two glasses within the Frit 320 - SB3 system (at 35 and 40\% WL, ADT-5 and ADT-6, respectively) resulted in normalized boron releases (NL [B]) of $\sim 1.5 \mathrm{~g} / \mathrm{L}$ and $\sim 2.0 \mathrm{~g} / \mathrm{L}$, respectively. Subsequent assessments of melt rate by Smith et al. (2004) indicated that the melt rate for the Frit 320 - SB3 system at 35\% WL was higher than the Frit 418 - SB3 system at 35\% WL - potentially a second significant opportunity missed to increase melt rate and/or waste throughput strictly due to the conservative decisions made by the current durability model.

To address this issue, an alternative strategy to improve WL and/or melt rate was proposed by Edwards et al. (2004) by establishing "less conservative" SME acceptability limits for durability without compromising product quality. Although the "new" limits allow access into compositional regions of interest (i.e., higher alkali systems) which can improve melt rate and/or waste loading, there may still be "additional" conservatism. In this report, two series of glasses were developed to challenge the "new" durability limits within the SB4 system. In the first series, the total alkali of the Frit 320-based glasses (designed to support the melt rate program) was increased from $20 \mathrm{wt} \%$ to $21 \mathrm{wt} \%$ (in the frit), and the series also evaluated the possible impact of various $\mathrm{Na}_{2} \mathrm{O}$ and $\mathrm{Li}_{2} \mathrm{O}$ mass ratio differences. The second series pushed the alkali limit in the frit even further with frits containing either 22 or $24 \mathrm{wt} \%$ total alkali as well as various $\mathrm{Na}_{2} \mathrm{O}$ and $\mathrm{Li}_{2} \mathrm{O}$ mass ratios. Again, the objective of these last two series of glasses was to challenge the durability model (using the less conservative limits as proposed by Edwards et al. (2004)) to assess if there is additional conservatism in the model which may provide further incentive to evaluate other alternative durability approaches.

This report provides a summary of the results associated with frits developed to support both melt rate testing and to challenge the current durability model. The compositional basis of the sludge

\footnotetext{
${ }^{1}$ Given the conservatism in the original $\Delta \mathrm{G}_{\mathrm{p}}$ limits, Edwards et al. (2004) provide a detailed discussion of the development of alternative (or less conservative) durability limits within the existing $\Delta \mathrm{G}_{\mathrm{P}}$ structure. These new $\Delta \mathrm{G}_{\mathrm{P}}$ limits have been proposed for implementation at DWPF but are not currently being used for the SB3 system.
} 
used to support these tests is defined in Section 2.0. Candidate frits designed to support melt rate assessments and to challenge the durability model are defined in Section 3.0. In Section 4.0, model based assessments are summarized which indicate the projected operating windows (or lack thereof) and the critical property that restricts access to higher WLs or completely eliminates the projected operating window. Based on the model-based assessments, specific glass compositions are defined from which experimental measurements of durability are performed. The specific glass compositions are defined in Section 5.0. Section 6.0 provides the experimental basis for this effort. Section 7.0 summarizes the results of the compositional analysis of the asfabricated glasses and the measured durability responses. Section 8.0 and 9.0 provide a summary of the work and recommendations for future work, respectively. 


\subsection{Baseline Sludge Composition}

Lilliston (2005) provided 20 different blended scenarios for SB4. The 1100 Canister Baseline option was selected as the baseline sludge composition to support experimental assessments of durability. ${ }^{2}$ Table 2-1 summarizes the 1100 Canister Baseline sludge composition (calcined oxide basis in $\mathrm{wt} \%)^{3}$

Table 2-1. Nominal SB4 Composition Used to Support Testing (from Lilliston 2005).

\begin{tabular}{||c|c||}
\hline Oxide & wt\% \\
\hline $\mathrm{Al}_{2} \mathrm{O}_{3}$ & 22.675 \\
\hline $\mathrm{BaO}$ & 0.162 \\
\hline $\mathrm{CaO}$ & 2.233 \\
\hline $\mathrm{Ce}_{2} \mathrm{O}_{3}$ & 0.208 \\
\hline $\mathrm{Cr}_{2} \mathrm{O}_{3}$ & 0.252 \\
\hline $\mathrm{CuO}$ & 0.084 \\
\hline $\mathrm{Fe}_{2} \mathrm{O}_{3}$ & 26.009 \\
\hline $\mathrm{K}_{2} \mathrm{O}$ & 1.025 \\
\hline $\mathrm{La}_{2} \mathrm{O}_{3}$ & 0.093 \\
\hline $\mathrm{MgO}$ & 1.942 \\
\hline $\mathrm{MnO}$ & 5.838 \\
\hline $\mathrm{Na}_{2} \mathrm{O}$ & 22.028 \\
\hline $\mathrm{NiO}$ & 3.715 \\
\hline $\mathrm{PbO}^{2}$ & 0.166 \\
\hline $\mathrm{SO}_{4}$ & 1.099 \\
\hline $\mathrm{SiO}_{2}$ & 2.732 \\
\hline $\mathrm{ThO}_{2}$ & 0.035 \\
\hline $\mathrm{TiO}_{2}$ & 0.021 \\
\hline $\mathrm{U}_{3} \mathrm{O}_{8}$ & 9.276 \\
\hline $\mathrm{ZnO}_{2 n O}$ & 0.128 \\
\hline $\mathrm{ZrO}_{2}$ & 0.279 \\
\hline $\mathrm{Total}$ & 100.00 \\
\hline
\end{tabular}

\footnotetext{
2 It is noted that prior to the issuance of this report, Elder (2005) issued revised SB4 compositions based on a decision not to include Tank 4 in SB4. The primary difference between the 1100 Canister Option provided by Lilliston (2005) and the revised baseline sludge provided by Elder (2005) is the projected $\mathrm{Al}_{2} \mathrm{O}_{3}$ concentration. Elder (2005) reports the projected $\mathrm{Al}_{2} \mathrm{O}_{3}$ concentration to be $~ 31 \%$ (calcined oxide basis) relative to the 22.65\% value shown in Table 3-1. Although differences do exist between the two projections, use of either sludge composition will meet the intent of this study as well as provide additional data to support SB4 flowsheet development activities.

3 Elementals for the 1100 Canister Baseline option reported by Lilliston (2005) were converted to oxides and normalized to represent the Sludge Receipt and Adjustment Tank (SRAT) product.
} 
WSRC-TR-2005-00306

Revision 0

\subsection{CANDIDATE FRITS}

Peeler and Edwards (2005) indicated that Frit 320 was a candidate for the SB4 1100 Canister Baseline option. The projected operating window (based on assessments of predicted properties relative to the SME acceptability criteria) was $25-43 \%$ WL with predictions of low viscosity (low $\eta$ ) limiting access to higher WLs. It should be noted that the "proposed" durability limits as defined by Edwards et al. (2004) were used in that assessment. If the original durability limits were used, Frit 320 would not be a viable candidate for this sludge option as the high alkali content of the frit coupled with the relatively high alkali content of the sludge would result in predictions of durability limiting its use.

\section{1 “20\% Total Alkali” Series}

As discussed in Section 1.0, there are three primary series of glasses to assess in this study. The first was based on the concept of "lower $\mathrm{Li}_{2} \mathrm{O}$ " frits to improve melt rate given the results of thermodynamic modeling efforts. This series of frits is summarized in Table 3-1. Frit 320 is considered to be a "high alkali" based frit with $8 \mathrm{wt} \% \mathrm{Li}_{2} \mathrm{O}$ and $12 \mathrm{wt} \% \mathrm{Na}_{2} \mathrm{O}$. The "low $\mathrm{Li}_{2} \mathrm{O}$ " frit series maintains a constant sum of alkali content (on a mass basis) at $20 \mathrm{wt} \%$, but reduces the $\mathrm{Li}_{2} \mathrm{O}$ concentration from $8 \mathrm{wt} \%$ down to $0 \mathrm{wt} \%$ in either $2 \%$ or $1 \%$ increments with the differences being accounted for by an increase in $\mathrm{Na}_{2} \mathrm{O}$ concentration. Although an equivalent sum of alkali mass basis is maintained, this series of $\mathrm{Li}_{2} \mathrm{O}$ concentrations transitions from a 1.41:1 molar $\mathrm{Na}_{2} \mathrm{O}: \mathrm{Li}_{2} \mathrm{O}$ ratio (Frit 320), to a 1:1 molar ratio (Frit 320r), and ultimately to a 1:14:1 molar ratio (Frit 320h). Note Frit 320i has no $\mathrm{Li}_{2} \mathrm{O}-$ only $20 \mathrm{wt} \% \mathrm{Na}_{2} \mathrm{O}$ by mass.

Table 3-1. Frit 320 and the "Low $\mathrm{Li}_{2} \mathrm{O}$ " Based Frit Compositions (wt\%)

\begin{tabular}{||c|c|c|c|c|c||}
\hline \hline Frit ID & $\mathbf{B}_{\mathbf{2}} \mathbf{O}_{\mathbf{3}}$ & $\mathbf{L i}_{\mathbf{2}} \mathbf{O}$ & $\mathbf{N a}_{\mathbf{2}} \mathbf{O}$ & $\mathbf{S i O}_{\mathbf{2}}$ & alkali \\
\hline 320 & 8 & 8 & 12 & 72 & 20 \\
\hline $320 \mathrm{f}$ & 8 & 6 & 14 & 72 & 20 \\
\hline $320 \mathrm{r}$ & 8 & 5 & 15 & 72 & 20 \\
\hline $320 \mathrm{~g}$ & 8 & 4 & 16 & 72 & 20 \\
\hline $320 \mathrm{~h}$ & 8 & 2 & 18 & 72 & 20 \\
\hline $320 \mathrm{i}$ & 8 & 0 & 20 & 72 & 20 \\
\hline
\end{tabular}

\subsection{Challenge to "Proposed” Durability Limits}

In the assessments performed by Peeler and Edwards (2005), Frit 320 was viable with the SB4 1100 Canister Baseline option given the use of the "proposed" durability limits. Also in that assessment, a frit containing $13 \mathrm{wt} \% \mathrm{Na}_{2} \mathrm{O}$ was assessed, which when coupled with the 1100 Canister Baseline option resulted in predictions of durability (even with the "proposed" limits) limiting access to lower WLs. The implication is that Frit 320 appears to be "on the edge" in terms of total alkali content and its impact on projected operating windows of interest.

Table 3-2 summarizes a series of frits developed to "challenge" the proposed durability limits when coupled with SB4 at 35\% WL (see Section 4.0 for details regarding the model based assessments) while also evaluating the impact of lower $\mathrm{Li}_{2} \mathrm{O}$ concentrations. Consider Frit 320n through Frit 320q in Table 3-2. This series of frits increases the total alkali content from $20 \mathrm{wt} \%$ (Frit 320 and the initial melt rate series - see Table 3-1) to $21 \%$ as well as partitioning the $\mathrm{Na}_{2} \mathrm{O}$ 
and $\mathrm{Li}_{2} \mathrm{O}$ differently. Frit 320n is based on $15 \mathrm{wt} \% \mathrm{Na}_{2} \mathrm{O}$ and $6 \mathrm{wt} \% \mathrm{Li}_{2} \mathrm{O}$. Subsequent frits are based on a $2 \%$ incremental increase in $\mathrm{Na}_{2} \mathrm{O}$ (maximum being 21\% in Frit 320q) with the difference being accounted for by a reduction in the $\mathrm{Li}_{2} \mathrm{O}$ concentration. Note Frit 320 (20 wt\% total alkali) is shown in Table 3-2 for comparison purposes.

Table 3-2. Candidate Frits Based on a 21 wt\% Total Alkali Content.

\begin{tabular}{||c|c|c|c|c|c||}
\hline \hline Frit ID & $\mathbf{B}_{2} \mathbf{O}_{3}$ & $\mathbf{L i}_{2} \mathbf{O}$ & $\mathbf{N a}_{2} \mathbf{O}$ & $\mathbf{S i O}_{2}$ & alkali \\
\hline 320 & 8 & 8 & 12 & 72 & 20 \\
\hline $320 \mathrm{n}$ & 8 & 6 & 15 & 71 & 21 \\
\hline $320 \mathrm{o}$ & 8 & 4 & 17 & 71 & 21 \\
\hline $320 \mathrm{p}$ & 8 & 2 & 19 & 71 & 21 \\
\hline $320 \mathrm{q}$ & 8 & 0 & 21 & 71 & 21 \\
\hline \hline
\end{tabular}

Table 3-3 summarizes a series of frit compositions (listed as Frit 320j through Frit 320m) that increase the total alkali content from $21 \%$ to either 22 or $24 \mathrm{wt} \%$. Based on previous assessments, this series of frits should result in complete elimination of the projected operating windows due to durability predictions even with the "proposed" limits (see Section 4.0 for more details). This series of frits also increases the $\mathrm{Na}_{2} \mathrm{O}$ concentration from $16 \%$ up to $22 \%$ with $\mathrm{Li}_{2} \mathrm{O}$ values decreasing from $6 \%$ down to $0 \%$. Frit $320 \mathrm{l}$ pushes the total alkali envelope the furthest given it targets a total alkali content of 24\%. Again, Frit 320 is shown in Table 3-3 for comparison purposes.

Table 3-3. Candidate Frits Based on a 22 or 24 wt\% Total Alkali Content.

\begin{tabular}{||c|c|c|c|c|c||}
\hline \hline Frit ID & $\mathbf{B}_{2} \mathbf{O}_{3}$ & $\mathbf{L i}_{\mathbf{2}} \mathbf{O}$ & $\mathbf{N a}_{\mathbf{2}} \mathbf{O}$ & $\mathbf{S i O}_{2}$ & \\
\hline 320 & 8 & 8 & 12 & 72 & 20 \\
\hline $320 \mathrm{j}$ & 8 & 6 & 16 & 70 & 22 \\
\hline $320 \mathrm{k}$ & 8 & 4 & 18 & 70 & 22 \\
\hline $320 \mathrm{l}$ & 8 & 2 & 22 & 68 & 24 \\
\hline $320 \mathrm{~m}$ & 8 & 0 & 22 & 70 & 22 \\
\hline
\end{tabular}




\subsection{MAR ASSESSMENTS}

Table 4-1 summarizes the model based Measurement Acceptability Region (MAR) assessments for the various frit - SB4 (1100 Canister Baseline) options over WLs from $25-60 \%$. The property predictions assessed in this study included durability (PCT [ASTM 2002] response in terms of the preliminary glass dissolution estimator $\left(\Delta \mathrm{G}_{\mathrm{P}}\right)$ (Jantzen et al. 1995)), viscosity at $1150^{\circ} \mathrm{C}\left(\eta_{1150^{\circ} \mathrm{C}}\right)$, liquidus temperature $\left(\mathrm{T}_{\mathrm{L}}\right)$, and $\mathrm{Al}_{2} \mathrm{O}_{3}$ and alkali concentrations. Jantzen et al. (1995) and Brown et al. (2001) provide a more detailed discussion on the development of these models. To establish or project operational windows for sludge/frit scenarios of interest, the predicted properties must be assessed relative to established acceptance criteria. Acceptable predicted properties for this assessment were based on the MAR limits. Brown, Postles, and Edwards (2002) provide a detailed discussion of how the MAR limits are utilized in the Product Composition Control System (PCCS). The results of the MAR assessment are discussed separately for each glass series in terms of meeting the task objectives.

Table 4-1. MAR Based Projected Operating Windows.

\begin{tabular}{|c|c|c|c|c|c|c|}
\hline & \multicolumn{6}{|c|}{20 wt\% Total Alkali Series } \\
\hline & LLow-Li-1 & Low-Li-2 & Low-Li-3 & LLow-Li-4 & Low-Li-5 & Low-Li-6 \\
\hline & Frit 320 & Frit 320f & Frit 320g & Frit 320h & Frit 320i & Frit 320r \\
\hline $\begin{array}{c}1100 \\
\text { Canister } \\
\text { Baseline }\end{array}$ & $\begin{array}{l}25-43 \\
(\text { low } \eta \text { ) }\end{array}$ & $\begin{array}{c}25-45 \\
\left(\mathrm{~T}_{\mathrm{L}}\right)\end{array}$ & $\begin{array}{c}25-45 \\
\left(T_{L}\right)\end{array}$ & $\begin{array}{c}25-45 \\
\left(\mathrm{~T}_{\mathrm{L}}\right)\end{array}$ & $\begin{array}{c}\text { (high } \eta \text { ) } \\
30-45 \\
\left(\mathrm{~T}_{\mathrm{L}}\right)\end{array}$ & $\begin{array}{c}25-45 \\
\left(T_{L}\right)\end{array}$ \\
\hline $\mathrm{Na}_{2} \mathrm{O}(\mathrm{wt} \%)$ & 12 & 14 & 16 & 18 & 20 & 15 \\
\hline $\mathrm{Li}_{2} \mathrm{O}(\mathrm{wt} \%)$ & 8 & 6 & 4 & 2 & 0 & 5 \\
\hline \multirow[t]{4}{*}{ Salkali } & 20 & 20 & 20 & 20 & 20 & 20 \\
\hline & \multicolumn{4}{|c|}{21 wt\% Total Alkali Series } & & \\
\hline & Low-Li-11 & Low-Li-12 & Low-Li-13 & Low-Li-14 & & \\
\hline & Frit 320n & Frit 320o & Frit 320p & Frit 320q & & \\
\hline 1100 & $\left(\Delta \mathrm{G}_{\mathrm{P}}\right)$ & $\left(\Delta \mathrm{G}_{\mathrm{P}}\right)$ & $\left(\Delta \mathrm{G}_{\mathrm{P}}\right)$ & $\left(\Delta \mathrm{G}_{\mathrm{P}}\right)$ & & \\
\hline Canister & $33-44$ & $37-46$ & $40-46$ & $43-46$ & & \\
\hline Baseline & (low $\eta$ ) & $\left(\mathrm{T}_{\mathrm{L}}\right)$ & $\left(\mathrm{T}_{\mathrm{L}}\right)$ & $\left(\mathrm{T}_{\mathrm{L}}\right)$ & & \\
\hline $\mathrm{Na}_{2} \mathrm{O}(\mathrm{wt} \%)$ & 15 & 17 & 19 & 21 & & \\
\hline $\mathrm{Li}_{2} \mathrm{O}(\mathrm{wt} \%)$ & 6 & 4 & 2 & 0 & & \\
\hline \multirow[t]{5}{*}{ Salkali } & 21 & 21 & 21 & 21 & & \\
\hline & & & & & & \\
\hline & \multicolumn{4}{|c|}{22 and $24 \mathrm{wt} \%$ Total Alkali Series } & & \\
\hline & Low-Li-7 & Low-Li-8 & Low-Li-9 & Low-Li-10 & & \\
\hline & Frit 320j & Frit 320k & Frit 3201 & Frit 320m & & \\
\hline $\begin{array}{c}1100 \\
\text { Canister } \\
\text { Baseline }\end{array}$ & $\left(\Delta \bar{G}_{\mathrm{P}}\right)$ & $\left(\Delta \bar{G}_{\mathrm{P}}\right)$ & $\left(\Delta \bar{G}_{\mathrm{P}}\right)$ & $\left(\Delta \bar{G}_{\mathrm{P}}\right)$ & & \\
\hline $\mathrm{Na}_{2} \mathrm{O}(\mathrm{wt} \%)$ & 16 & 18 & 22 & 22 & & \\
\hline $\mathrm{Li}_{2} \mathrm{O}(\mathrm{wt} \%)$ & 6 & 4 & 2 & 0 & & \\
\hline Salkali & 22 & 22 & 24 & 22 & & \\
\hline
\end{tabular}


WSRC-TR-2005-00306

Revision 0

\section{1 “20 wt\% Total Alkali” Series}

This series of glasses were designed specifically to support assessment of melt rate - not designed to challenge durability predictions. The MAR assessments for the " $20 \mathrm{wt} \%$ total alkali" series indicate that transitioning to a higher $\mathrm{Na}_{2} \mathrm{O}$ content increases the projected operating window relative to the Frit 320 - SB4 system. More specifically, the Frit 320 - SB4 system has a projected operating window of $25-43 \%$ WL with low viscosity limiting access to higher WLs. Increasing the $\mathrm{Na}_{2} \mathrm{O}$ content from $12 \mathrm{wt} \%$ to $14 \mathrm{wt} \%$ while simultaneously reducing the $\mathrm{Li}_{2} \mathrm{O}$ content (Frit 320f) increases the upper WL limit from 43\% (low viscosity limited) to $45 \%\left(\mathrm{~T}_{\mathrm{L}}\right.$ limited). The transition from a low viscosity limited system to a $T_{L}$ limited system agrees with glass science theory as (in general) $\mathrm{Li}_{2} \mathrm{O}$ lowers the viscosity of a glass system more dramatically as compared to $\mathrm{Na}_{2} \mathrm{O}$. Thus, by decreasing the $\mathrm{Li}_{2} \mathrm{O}$ content, the predicted viscosities of the glasses at 44 and $45 \%$ WL increase and become "acceptable" at the MAR. This opens up the operating window to higher WLs and transitions the limiting property from low viscosity to $\mathrm{T}_{\mathrm{L}}$. However, the increase in $\mathrm{Na}_{2} \mathrm{O}$ from $12 \%$ to $14 \mathrm{wt} \%$ (or reduction in $\mathrm{Li}_{2} \mathrm{O}$ from $8 \mathrm{wt} \%$ to $6 \mathrm{wt} \%$ ) appears to be a critical step as further $\mathrm{Na}_{2} \mathrm{O}$ increases (or $\mathrm{Li}_{2} \mathrm{O}$ reductions) do not have the predicted positive impact (i.e., projected operating windows for 320r, 320g, and 320h are still limited to $45 \% \mathrm{WL}$ ). This is based on the fact that $\mathrm{T}_{\mathrm{L}}$ now dictates these systems, and the $\mathrm{T}_{\mathrm{L}}$ model is apparently not as sensitive to the varying ratios of $\mathrm{Li}_{2} \mathrm{O}$ and $\mathrm{Na}_{2} \mathrm{O}$ - but may be driven based on the total alkali content which is being held constant at $20 \mathrm{wt} \%$. At $0 \% \mathrm{Li}_{2} \mathrm{O}$ (Frit 320i), the projected operating window becomes limited by high viscosity on the low WL side (25 $29 \%$ ) while remaining limited at $45 \% \mathrm{WL}$ on the upper $\mathrm{WL}$ side due to $\mathrm{T}_{\mathrm{L}}$ predictions.

\section{2 “21 wt\% Total Alkali” Series}

As previously discussed, this series of glasses (Frit 320n through Frit 320q) was developed to "challenge" the proposed durability limits and to begin "pushing the envelope" in terms of $\mathrm{Na}_{2} \mathrm{O}$ additions (data that could potentially be used to improve melt rate and/or waste loading for SB4 or future sludge batches). The MAR results suggest that the $1 \%$ increase in total alkali content does introduce significant limitations to the projected operating windows via predictions of durability - meeting programmatic objectives for this series. Although projected operating windows do exist for this series of frits, durability (represented by the $\Delta \mathrm{G}_{\mathrm{P}}$ symbol in Table 4-1) begins to limit access to lower WLs. That is, at lower WLs the model suggests that durability (as measured by the PCT) will be an issue for glasses based on this series of frits.

As the $\mathrm{Na}_{2} \mathrm{O}$ concentration (in the frit) increases for this series, the minimum "acceptable” WL also increases (durability becomes more of an issue with the higher $\mathrm{Na}_{2} \mathrm{O}$ based frits and/or the partitioning of $\mathrm{Na}_{2} \mathrm{O}$ to $\mathrm{Li}_{2} \mathrm{O}$ ). With lower WLs continuing to be restricted as a function of $\mathrm{Na}_{2} \mathrm{O}$ content, the overall window size continually decreases given the upper WL limit is relatively consistent $(44-46 \%)$. It should also be noted that a $1 \%$ increase in total alkali content (from $20 \%$ to $21 \mathrm{wt} \%$ ) apparently reduces the predicted $\mathrm{T}_{\mathrm{L}}$ values which typically results in access to higher WLs (46\% WL for this series as compared to 45\% WL for the "20 wt\% total alkali" series developed to support melt rate). The Frit 320n system is an exception to this latter statement as this system continues to be low viscosity limited (as is the Frit 320 based system). However, comparing Frit 320n to Frit 320, it appears that although the total alkali content has increased by $1 \%$, the difference in partitioning or ratios does have a positive impact on the upper WL achievable.

\section{3 “22 wt\% or 24 wt\% Total Alkali” Series}


The primary purpose of this series of frits (Frit 320j through Frit 320m) was to continue pushing the "total alkali envelope" to the point where durability predictions become a significant issue.

Based on the MAR results as shown in Table 4-1, this objective was accomplished given there are no operating windows for any of the " $22 \mathrm{wt} \%$ or $24 \mathrm{wt} \%$ total alkali" frits. The durability model (even with the less conservative durability limits) indicates that "non-durable" products would be produced over the entire $25-60 \%$ WL range for each of the four frits. An experimental assessment of durability via the PCT will either confirm this prediction or provide data that suggest that there may be additional conservatism in the "proposed" limits. 
WSRC-TR-2005-00306

Revision 0

\subsection{CANDIDATE GLASSES}

In this section, 14 glasses are identified from which experimental assessments of durability will be evaluated. The 14 glasses will be based on the nominal SB4 1100 Canister Baseline sludge composition (see Table 2-1) coupled with each of the 14 frit compositions. The only input still required to develop specific glass compositions is the targeted WL. The selected WL should be one at which the "low $\mathrm{Li}_{2} \mathrm{O}$ " based frits (in support of melt rate) are considered processable (or acceptable), while the higher total alkali frits are considered "unacceptable" from a durability perspective (i.e., challenge the proposed durability limits). A WL of 35\% was selected to meet this criterion - the only exception would be the Frit 320n glass at 35\% WL (a $21 \mathrm{wt} \%$ total alkali frit) that is considered acceptable based on the projected operating window of $33-44 \% \mathrm{WL}$. However, selecting a WL $<33 \%$ may be undesirable given recent DWPF WL targets of 35\% or higher. Higher WLs (> 44\%) are not feasible given most, if not all, of the systems are either $\mathrm{T}_{\mathrm{L}}$ or low viscosity limited at $45-46 \% \mathrm{WL}$.

Tables 5-1 through 5-3 summarize the targeted compositions for the " $20 \mathrm{wt} \%$ total alkali" series (labeled Low-Li-1 through Low-Li-6), "21 wt\% total alkali” series (labeled Low-Li-7 through Low-Li-10), and the " 22 - 24 wt\% total alkali” series (labeled Low-Li-11 through Low-Li-14), respectively. 
Table 5-1. “20 wt\% Total Alkali” Series: Target Glass Compositions.

\begin{tabular}{||c|c|c|c|c|c|c||}
\hline \hline Glass ID & Low-Li-1 & Low-Li-2 & Low-Li-3 & Low-Li-4 & Low-Li-5 & Low-Li-6 \\
\hline Frit ID & $\mathbf{3 2 0}$ & $\mathbf{3 2 0 f}$ & $\mathbf{3 2 0 g}$ & $\mathbf{3 2 0 h}$ & $\mathbf{3 2 0 i}$ & $\mathbf{3 2 0 r}$ \\
\hline Oxide & & & & & & \\
\hline $\mathrm{Al}_{2} \mathrm{O}_{3}$ & 8.025 & 8.025 & 8.025 & 8.025 & 8.025 & 8.025 \\
\hline $\mathrm{B}_{2} \mathrm{O}_{3}$ & 5.200 & 5.200 & 5.200 & 5.200 & 5.200 & 5.200 \\
\hline $\mathrm{BaO}$ & 0.057 & 0.057 & 0.057 & 0.057 & 0.057 & 0.057 \\
\hline $\mathrm{CaO}$ & 0.790 & 0.790 & 0.790 & 0.790 & 0.790 & 0.790 \\
\hline $\mathrm{Ce}_{2} \mathrm{O}_{3}$ & 0.074 & 0.074 & 0.074 & 0.074 & 0.074 & 0.074 \\
\hline $\mathrm{Cr}_{2} \mathrm{O}_{3}$ & 0.089 & 0.089 & 0.089 & 0.089 & 0.089 & 0.089 \\
\hline $\mathrm{CuO}$ & 0.030 & 0.030 & 0.030 & 0.030 & 0.030 & 0.030 \\
\hline $\mathrm{Fe}_{2} \mathrm{O}_{3}$ & 9.204 & 9.204 & 9.204 & 9.204 & 9.204 & 9.204 \\
\hline $\mathrm{K}_{2} \mathrm{O}$ & 0.363 & 0.363 & 0.363 & 0.363 & 0.363 & 0.363 \\
\hline $\mathrm{La}_{2} \mathrm{O}_{3}$ & 0.033 & 0.033 & 0.033 & 0.033 & 0.033 & 0.033 \\
\hline $\mathrm{Li}_{2} \mathrm{O}$ & 5.200 & 3.900 & 2.600 & 1.300 & 0.000 & 3.250 \\
\hline $\mathrm{MgO}_{\mathrm{MnO}}$ & 0.687 & 0.687 & 0.687 & 0.687 & 0.687 & 0.687 \\
\hline $\mathrm{MnO}_{2}$ & 2.066 & 2.066 & 2.066 & 2.066 & 2.066 & 2.066 \\
\hline $\mathrm{Na}_{2} \mathrm{O}$ & 15.595 & 16.895 & 18.195 & 19.495 & 20.795 & 17.545 \\
\hline $\mathrm{NiO}^{2}$ & 1.315 & 1.315 & 1.315 & 1.315 & 1.315 & 1.315 \\
\hline $\mathrm{PbO}_{b}$ & 0.059 & 0.059 & 0.059 & 0.059 & 0.059 & 0.059 \\
\hline $\mathrm{SiO}_{2}$ & 47.767 & 47.767 & 47.767 & 47.767 & 47.767 & 47.767 \\
\hline $\mathrm{ThO}_{2}$ & 0.012 & 0.012 & 0.012 & 0.012 & 0.012 & 0.012 \\
\hline $\mathrm{TiO}_{2}$ & 0.008 & 0.008 & 0.008 & 0.008 & 0.008 & 0.008 \\
\hline $\mathrm{U}_{3} \mathrm{O}_{8}$ & 3.283 & 3.283 & 3.283 & 3.283 & 3.283 & 3.283 \\
\hline $\mathrm{ZnO}_{\mathrm{ZrO}}$ & 0.045 & 0.045 & 0.045 & 0.045 & 0.045 & 0.045 \\
\hline & 0.099 & 0.099 & 0.099 & 0.099 & 0.099 & 0.099 \\
\hline $\mathrm{Total}_{2}$ & 100.0 & 100.0 & 100.0 & 100.0 & 100.0 & 100.0 \\
\hline \hline
\end{tabular}


Table 5-2. “21 wt\% Total Alkali” Series: Target Glass Compositions.

\begin{tabular}{||c|c|c|c|c||}
\hline \hline Glass ID & Low-Li-7 & Low-Li-8 & Low-Li-9 & Low-Li-10 \\
\hline Frit ID & $\mathbf{3 2 0 j}$ & $\mathbf{3 2 0 k}$ & $\mathbf{3 2 0 1}$ & $\mathbf{3 2 0 m}$ \\
\hline Oxide & & & & \\
\hline $\mathrm{Al}_{2} \mathrm{O}_{3}$ & 8.025 & 8.025 & 8.025 & 8.025 \\
\hline $\mathrm{B}_{2} \mathrm{O}_{3}$ & 5.200 & 5.200 & 5.200 & 5.200 \\
\hline $\mathrm{BaO}$ & 0.057 & 0.057 & 0.057 & 0.057 \\
\hline $\mathrm{CaO}$ & 0.790 & 0.790 & 0.790 & 0.790 \\
\hline $\mathrm{Ce}_{2} \mathrm{O}_{3}$ & 0.074 & 0.074 & 0.074 & 0.074 \\
\hline $\mathrm{Cr}_{2} \mathrm{O}_{3}$ & 0.089 & 0.089 & 0.089 & 0.089 \\
\hline $\mathrm{CuO} \mathrm{O}$ & 0.030 & 0.030 & 0.030 & 0.030 \\
\hline $\mathrm{Fe}_{2} \mathrm{O}_{3}$ & 9.204 & 9.204 & 9.204 & 9.204 \\
\hline $\mathrm{K}_{2} \mathrm{O}$ & 0.363 & 0.363 & 0.363 & 0.363 \\
\hline $\mathrm{La}_{2} \mathrm{O}_{3}$ & 0.033 & 0.033 & 0.033 & 0.033 \\
\hline $\mathrm{Li}_{2} \mathrm{O}$ & 3.900 & 2.600 & 1.300 & 0.000 \\
\hline $\mathrm{MgO}_{\mathrm{MnO}}$ & 0.687 & 0.687 & 0.687 & 0.687 \\
\hline $\mathrm{MnO}_{2} \mathrm{O}$ & 18.196 & 2.066 & 2.066 & 2.066 \\
\hline $\mathrm{Na}_{2} \mathrm{O}$ & 19.495 & 22.095 & 22.095 \\
\hline $\mathrm{NiO}_{\mathrm{PbO}}$ & 1.315 & 1.315 & 1.315 & 1.315 \\
\hline $\mathrm{SiO}_{2}$ & 46.467 & 46.467 & 45.167 & 46.467 \\
\hline $\mathrm{ThO}_{2}$ & 0.012 & 0.012 & 0.012 & 0.012 \\
\hline $\mathrm{TiO}_{2}$ & 0.008 & 0.008 & 0.008 & 0.008 \\
\hline $\mathrm{U}_{3} \mathrm{O}_{8}$ & 3.283 & 3.283 & 3.283 & 3.283 \\
\hline $\mathrm{ZnO}_{2 \mathrm{O}}$ & 0.045 & 0.045 & 0.045 & 0.045 \\
\hline $\mathrm{ZrO}_{2}$ & 0.099 & 0.099 & 0.099 & 0.099 \\
\hline & & & & \\
\hline $\mathrm{Total}$ & 100.0 & 100.0 & 100.0 & 100.0 \\
\hline \hline
\end{tabular}


Table 5-3. “21 wt\% Alkali” Series: Target Glass Compositions.

\begin{tabular}{||c|c|c|c|c||}
\hline \hline Glass ID & Low-Li-11 & Low-Li-12 & Low-Li-13 & Low-Li-14 \\
\hline Frit ID & $\mathbf{3 2 0 n}$ & $\mathbf{3 2 0 0}$ & $\mathbf{3 2 0 p}$ & $\mathbf{3 2 0 q}$ \\
\hline Oxide & & & & \\
\hline $\mathrm{Al}_{2} \mathrm{O}_{3}$ & 8.025 & 8.025 & 8.025 & 8.025 \\
\hline $\mathrm{B}_{2} \mathrm{O}_{3}$ & 5.200 & 5.200 & 5.200 & 5.200 \\
\hline $\mathrm{BaO}$ & 0.057 & 0.057 & 0.057 & 0.057 \\
\hline $\mathrm{CaO}$ & 0.790 & 0.790 & 0.790 & 0.790 \\
\hline $\mathrm{Ce}_{2} \mathrm{O}_{3}$ & 0.074 & 0.074 & 0.074 & 0.074 \\
\hline $\mathrm{Cr}_{2} \mathrm{O}_{3}$ & 0.089 & 0.089 & 0.089 & 0.089 \\
\hline $\mathrm{CuO}$ & 0.030 & 0.030 & 0.030 & 0.030 \\
\hline $\mathrm{Fe}_{2} \mathrm{O}_{3}$ & 9.204 & 9.204 & 9.204 & 9.204 \\
\hline $\mathrm{K}_{2} \mathrm{O}$ & 0.363 & 0.363 & 0.363 & 0.363 \\
\hline $\mathrm{La}_{2} \mathrm{O}_{3}$ & 0.033 & 0.033 & 0.033 & 0.033 \\
\hline $\mathrm{Li}_{2} \mathrm{O}$ & 3.900 & 2.600 & 1.300 & 0.000 \\
\hline $\mathrm{MgO} \mathrm{O}$ & 0.687 & 0.687 & 0.687 & 0.687 \\
\hline $\mathrm{MnO} \mathrm{Na}_{2} \mathrm{O}$ & 2.066 & 2.066 & 2.066 & 2.066 \\
\hline $\mathrm{NiO}$ & 17.545 & 18.845 & 20.145 & 21.445 \\
\hline $\mathrm{PbO}_{\mathrm{SiO}}$ & 0.059 & 0.059 & 0.059 & 0.059 \\
\hline $\mathrm{ThO}_{2}$ & 0.012 & 0.012 & 0.012 & 0.012 \\
\hline $\mathrm{TiO}_{2}$ & 0.008 & 0.008 & 0.008 & 0.008 \\
\hline $\mathrm{U}_{3} \mathrm{O}_{8}$ & 3.283 & 3.283 & 3.283 & 3.283 \\
\hline $\mathrm{ZnO}$ & 0.045 & 0.045 & 0.045 & 0.045 \\
\hline $\mathrm{ZrO}_{2}$ & 0.099 & 0.099 & 0.099 & 0.099 \\
\hline & & & & \\
\hline $\mathrm{Total}$ & 100.000 & 100.000 & 100.000 & 100.000 \\
\hline \hline
\end{tabular}


WSRC-TR-2005-00306

Revision 0

\subsection{EXPERIMENTAL}

Each glass was prepared from the proper proportions of reagent-grade metal oxides, carbonates, $\mathrm{H}_{3} \mathrm{BO}_{3}$, and salts in a 150-g batch using the SRNL technical procedure "Glass Batching" (SRNL 2002a). Batch sheets were filled out as the materials were weighed. Once batched, the glasses were melted using SRNL technical procedure “Glass Melting” (SRNL 2002b). The thoroughly mixed raw materials were placed in a 95\% Platinum/5\% Gold 250-mL crucible and subsequently inserted into a high-temperature furnace at the target melt temperature of $1150^{\circ} \mathrm{C}$. After an isothermal hold at $1150^{\circ} \mathrm{C}$ for $1.0 \mathrm{~h}$, the crucible was removed, and the glass was poured onto a clean stainless steel plate and allowed to air cool.

Approximately $140 \mathrm{~g}$ of glass was removed (poured) from the crucible while $\sim 10 \mathrm{~g}$ remained in the crucible along the walls. The pour patty was used as a sampling stock for the various chemical and physical property measurements (i.e., chemical composition and durability).

\subsection{Chemical Composition Analysis}

To confirm that the "as-fabricated" glasses corresponded to the defined target compositions, a representative sample from each glass pour patty was submitted to the SRNL Mobile Laboratory (SRNL-ML) for chemical analysis. Standard dissolutions techniques were used to prepare the samples for Inductively Couple Plasma (ICP) analysis. ${ }^{4}$

\subsection{Product Consistency Test (PCT)}

The PCT was performed in triplicate on each "quenched" (q) glass to assess chemical durability using technical procedure "Standard Test Methods for Determining Chemical Durability of Nuclear Waste Glasses: The Product Consistency Test (PCT)” (ASTM 2002). Also included in this experimental test matrix were the EA glass (Jantzen et al. 1993), the Approved Reference Material (ARM) glass, and blanks. Samples were ground, washed, and prepared according to procedure. Fifteen milliliters of Type I ASTM water were added to $1.5 \mathrm{~g}$ of glass in stainless steel vessels. The vessels were closed, sealed, and placed in an oven at $90 \pm 2{ }^{\circ} \mathrm{C}$ where the samples were maintained for 7 days. The resulting solutions (once cooled) were sampled (filtered and acidified), labeled (according to the analytical plan), and analyzed. Normalized release rates were calculated based on targeted compositions using the average of the logs of the leachate concentrations.

To bound the effects of thermal history on the product performance, approximately $25 \mathrm{~g}$ of each glass were heat treated to simulate cooling along the centerline of a DWPF-type canister (Marra and Jantzen 1993). This cooling regime is commonly referred to as the centerline canister cooled (сcc) curve. This terminology will be used in this report to differentiate samples from different cooling regimes (q versus $\mathrm{ccc}$ ). PCTs were conducted in triplicate for these glasses.

\footnotetext{
4 Two dissolution techniques were used to support the compositional analysis: sodium peroxide fusion and lithiummetaborate. Samples prepared by sodium peroxide fusion dissolution were used to measure elemental concentrations of boron (B), lithium ( $\mathrm{Li}$ ) and nickel (Ni). All other elemental concentrations were obtained using the lithiummetaborate dissolution technique.
} 
WSRC-TR-2005-00306

Revision 0

\subsection{Results and Discussion}

\subsection{Compositional Analysis}

Tables A.1 through A.3 (see Appendix A) summarize the target versus measured compositions for the three series of study glasses (" $20 \mathrm{wt} \%$ alkali", " $21 \mathrm{wt} \%$ alkali" and " 22 and $2 \mathrm{wt} 4 \%$ alkali" series, respectively). ${ }^{5}$ A review of the target versus measured compositions suggests that no significant batching errors were committed during the fabrication of these glasses. This latter statement is based on the use of a $\pm 10 \%$ relative difference between target and measured values for the "major" oxides (i.e., those oxides present in the glass at $0.5 \mathrm{wt} \%$ or greater). For those oxides $<0.5 \mathrm{wt} \%$, high relative differences are expected and are not a practical concern. The only possible exceptions (based on the $\pm 10 \%$ relative difference on the major oxides) are associated with $\mathrm{MnO}$ and $\mathrm{U}_{3} \mathrm{O}_{8}$ for all study glasses and $\mathrm{Li}_{2} \mathrm{O}$ for Low-Li-4, Low-Li-9, and LowLi-13 (which are given in "red" in the appropriate tables in Appendix A). With respect to the $\mathrm{MnO}$ values, the analysis of the Batch 1 standard glass (see Table A.4 in Appendix A) suggests that the ICP analysis may be "biased" high as the measured $\mathrm{MnO}$ concentration for that glass is $2.13 \mathrm{wt} \%$ while the target (or "known") MnO concentration is $1.726 \mathrm{wt} \%$ - or a $23.4 \%$ relative difference. This relative difference is "consistent" with the \% relative differences observed for the "unknown" or study glasses.

The Batch 1 standard glass does not contain $\mathrm{U}_{3} \mathrm{O}_{8}$; therefore, there is no way to assess whether the measured values for the study glasses are biased "low" as indicated by the \% relative difference value (ranging from $\sim 10$ to $20 \mathrm{wt} \%$ low for the study glasses).

With respect to the three measured $\mathrm{Li}_{2} \mathrm{O}$ values that appear to be biased high (when compared to targeted values), the \% relative differences range from $10.7 \%$ to $13.1 \%$ - which are not of practical concern although given the self-imposed definition are classified as being "different." To provide further insight, the target $\mathrm{Li}_{2} \mathrm{O}$ values for each of the three glasses is $1.3 \mathrm{wt} \%$ with measured values being 1.47, 1.44, and $1.46 \mathrm{wt} \%$ for Low-Li-4, -9 , and -13 , respectively. Again, the values do not represent a significant or practical concern. In addition, the PCT response will be assessed based both on targeted and measured compositions so this impact can be assessed.

\subsection{PCT Assessments}

Table 7-1 summarizes the normalized release values based on target compositions for the study glasses (both q and ccc versions). Table 7-2 summarizes the normalized release values based on measured compositions for both the quenched and ccc versions of the study glasses.

Again, the normalized PCT responses shown are the average values for triplicate analyses. ${ }^{6}$

All of the study glasses are acceptable as defined by their NL [B]'s as compared to the EA glass (with a $16.695 \mathrm{~g} / \mathrm{L} \mathrm{NL}$ [B]) - regardless of the compositional view (measured or target) or thermal heat treatment. Using the targeted values, the most durable glass (based on NL [B]) is Low-Li-2 (сcс) with a $0.59 \mathrm{~g} / \mathrm{L}$ release. This glass is one of the " $20 \mathrm{wt} \%$ total alkali" series glasses which "agrees” with the expectations that lower total alkali glasses should (in general) have better durability (i.e., less of a negative impact on durability). Although Low-Li-2 is the most durable, the remaining “20 wt\% total alkali” glasses (both q and ccc versions) have NL [B]'s

\footnotetext{
5 The chemical composition raw data can be found in WSRC-NB-2004-00134, p. 170. In addition to the target vs. measured compositions, the \% relative difference is shown in Tables A.1 - A.3. Table A.4 summarizes the target versus measured compositions for the Batch 1 standard glasses that was analyzed with the study glasses.

6 The PCT raw data can be found in WSRC-NB-2004-00134, p. 171.
} 
between $0.76 \mathrm{~g} / \mathrm{L}$ (Low-Li-4 ccc) and 1.02 (Low-Li-1 quenched) - again all very acceptable as compared to EA.

The least durable glass (based on NL [B] and target compositions) is Low-Li-7 (quenched) with a NL [B] of $1.11 \mathrm{~g} / \mathrm{L}$. Given the higher concentration of alkali (a glass within the " $22-24 \mathrm{wt} \%$ total alkali" series), it is not surprising that the least durable glass comes out of this grouping. However, the $1.1079 \mathrm{~g} / \mathrm{L}$ is well below the benchmark of $16.695 \mathrm{~g} / \mathrm{L}$ for the EA glass. In terms of programmatic objectives, all of the " $21 \mathrm{wt} \%$ total alkali" and " $22-24 \mathrm{wt} \%$ total alkali" glasses, with the exception of Low-Li-11, fail the MAR criteria for durability. With the measured PCT responses being acceptable (i.e., all $<1.1079 \mathrm{~g} / \mathrm{L}$ ), the results suggest additional conservatism exists within the current durability model even with the "proposed" limits. More specifically, the "proposed" limits still appear to restrict access to compositional regions of interest (higher alkali glasses) even though their measured PCT responses are acceptable.

The information presented in Table 7-2 (based on measured compositions) is in agreement with the statements made above. Although there were some issues associated with $\mathrm{MnO}$ for all of the glasses and $\mathrm{Li}_{2} \mathrm{O}$ for three, the differences between target and measured normalized releases are not of practical concern and would lead one to the same conclusions. 
Table 7-1. Normalized PCT Response for the Study Glasses (g/L). (normalized based on target compositions) ${ }^{7}$

\begin{tabular}{|c|c|c|c|c|c|c|}
\hline Glass ID & $\begin{array}{c}\text { Heat } \\
\text { Treatment }\end{array}$ & $\begin{array}{l}\text { Comp } \\
\text { View }\end{array}$ & $\begin{array}{c}\mathrm{NL} \\
\mathrm{B}(\mathrm{g} / \mathrm{L})\end{array}$ & $\begin{array}{c}\text { NL Li } \\
(\mathrm{g} / \mathrm{L})\end{array}$ & $\begin{array}{c}\text { NL Na } \\
(g / L)\end{array}$ & $\begin{array}{l}\text { NL Si } \\
(\mathrm{g} / \mathrm{L})\end{array}$ \\
\hline ARM & - & reference & 0.60 & 0.54 & 1.01 & 0.30 \\
\hline EA & - & reference & 18.18 & 10.81 & 7.67 & 3.45 \\
\hline Low-Li-1 & quenched & target & 1.02 & 0.99 & 1.32 & 0.64 \\
\hline Low-Li-2 & quenched & target & 0.87 & 0.86 & 1.21 & 0.57 \\
\hline Low-Li-3 & quenched & target & 0.82 & 0.80 & 1.20 & 0.55 \\
\hline Low-Li-4 & quenched & target & 0.77 & 0.69 & 1.17 & 0.06 \\
\hline Low-Li-5 & quenched & target & 0.79 & - & 1.29 & 0.54 \\
\hline Low-Li-6 & quenched & target & 0.90 & 0.88 & 1.32 & 0.59 \\
\hline Low-Li-7 & quenched & target & 1.11 & 1.05 & 1.59 & 0.71 \\
\hline Low-Li-8 & quenched & target & 0.99 & 0.89 & 1.50 & 0.65 \\
\hline Low-Li-9 & quenched & target & 1.10 & 0.84 & 1.76 & 0.72 \\
\hline Low-Li-10 & quenched & target & 0.98 & - & 1.60 & 0.65 \\
\hline Low-Li-11 & quenched & target & 1.03 & 1.01 & 1.49 & 0.67 \\
\hline Low-Li-12 & quenched & target & 0.92 & 0.87 & 1.46 & 0.62 \\
\hline Low-Li-13 & quenched & target & 0.88 & 0.73 & 1.38 & 0.59 \\
\hline Low-Li-14 & quenched & target & 0.88 & - & 1.51 & 0.58 \\
\hline Low-Li-1 & CCC & target & 1.01 & 1.09 & 1.29 & 0.66 \\
\hline Low-Li-2 & $\overline{\mathrm{CCC}}$ & target & 0.59 & 0.62 & 0.78 & - \\
\hline Low-Li-3 & CCC & target & 0.77 & 0.81 & 1.08 & 0.52 \\
\hline Low-Li-4 & $\overline{\mathrm{CCC}}$ & target & 0.76 & 0.74 & 1.12 & 0.52 \\
\hline Low-Li-5 & CCC & target & 0.77 & - & 1.21 & 0.52 \\
\hline Low-Li-6 & CCC & target & 0.83 & 0.87 & 1.19 & 0.56 \\
\hline Low-Li-7 & CCC & target & 1.00 & 1.05 & 1.43 & 0.67 \\
\hline Low-Li-8 & $\overline{\text { CCC }}$ & target & 0.94 & 0.93 & 1.36 & 0.63 \\
\hline Low-Li-9 & CCC & target & 1.05 & 0.90 & 1.63 & 0.70 \\
\hline Low-Li-10 & $\overline{\mathrm{CCC}}$ & target & 0.93 & - & 1.50 & 0.62 \\
\hline Low-Li-11 & CCC & target & 0.96 & 1.01 & 1.36 & 0.63 \\
\hline Low-Li-12 & $\overline{\mathrm{CCC}}$ & target & 0.87 & 0.90 & 1.34 & 0.59 \\
\hline Low-Li-13 & $\overline{C C C}$ & target & 0.81 & 0.77 & 1.26 & 0.54 \\
\hline Low-Li-14 & $\overline{\text { CCC }}$ & target & 0.83 & - & 1.36 & 0.56 \\
\hline
\end{tabular}

\footnotetext{
${ }^{7}$ Note that for those glasses based on $0 \% \mathrm{Li}_{2} \mathrm{O}$ frits, a “““ is shown in the NL [Li] g/L column.
} 
Table 7-2. Normalized PCT Response for the Study Glasses (g/L). (normalized based on measured compositions) ${ }^{8}$

\begin{tabular}{|c|c|c|c|c|c|c|}
\hline Glass ID & $\begin{array}{c}\text { Heat } \\
\text { Treatment }\end{array}$ & $\begin{array}{l}\text { Comp } \\
\text { View }\end{array}$ & $\begin{array}{c}\mathrm{NL} \\
\mathrm{B}(\mathrm{g} / \mathrm{L})\end{array}$ & $\begin{array}{c}\mathbf{N L ~ L i} \\
(\mathrm{g} / \mathrm{L})\end{array}$ & $\begin{array}{c}\text { NL Na } \\
(\mathrm{g} / \mathrm{L})\end{array}$ & $\begin{array}{l}\text { NL Si } \\
(g / L)\end{array}$ \\
\hline ARM & - & reference & 0.60 & 0.54 & 1.01 & 0.30 \\
\hline EA & - & reference & 18.18 & 10.81 & 7.67 & 3.45 \\
\hline Low-Li-1 & quenched & Measured & 0.95 & 0.99 & 1.29 & 0.63 \\
\hline Low-Li-2 & quenched & Measured & 0.84 & 0.85 & 1.18 & 0.57 \\
\hline Low-Li-3 & quenched & Measured & 0.78 & 0.77 & 1.17 & 0.55 \\
\hline Low-Li-4 & quenched & Measured & 0.73 & 0.61 & 1.14 & 0.06 \\
\hline Low-Li-5 & quenched & Measured & 0.76 & - & 1.23 & 0.53 \\
\hline Low-Li-6 & quenched & Measured & 0.83 & 0.85 & 1.27 & 0.58 \\
\hline Low-Li-7 & quenched & Measured & 1.06 & 1.04 & 1.54 & 0.69 \\
\hline Low-Li-8 & quenched & Measured & 0.95 & 0.87 & 1.47 & 0.64 \\
\hline Low-Li-9 & quenched & Measured & 1.04 & 0.76 & 1.74 & 0.71 \\
\hline Low-Li-10 & quenched & Measured & 0.93 & - & 1.53 & 0.64 \\
\hline Low-Li-11 & quenched & Measured & 0.95 & 1.00 & 1.46 & 0.67 \\
\hline Low-Li-12 & quenched & Measured & 0.89 & 0.82 & 1.38 & 0.60 \\
\hline Low-Li-13 & quenched & Measured & 0.85 & 0.65 & 1.32 & 0.57 \\
\hline Low-Li-14 & quenched & Measured & 0.85 & - & 1.42 & 0.57 \\
\hline Low-Li-1 & CCC & Measured & 0.94 & 1.09 & 1.26 & 0.66 \\
\hline Low-Li-2 & CCC & Measured & 0.57 & 0.61 & 0.76 & - \\
\hline Low-Li-3 & CCC & Measured & 0.74 & 0.78 & 1.06 & 0.51 \\
\hline Low-Li-4 & CCC & Measured & 0.73 & 0.66 & 1.09 & 0.51 \\
\hline Low-Li-5 & CCC & Measured & 0.74 & - & 1.15 & 0.52 \\
\hline Low-Li-6 & CCC & Measured & 0.78 & 0.84 & 1.14 & 0.55 \\
\hline Low-Li-7 & CCC & Measured & 0.95 & 1.05 & 1.39 & 0.66 \\
\hline Low-Li-8 & CCC & Measured & 0.90 & 0.91 & 1.32 & 0.62 \\
\hline Low-Li-9 & CCC & Measured & 1.00 & 0.81 & 1.61 & 0.69 \\
\hline Low-Li-10 & CCC & Measured & 0.88 & - & 1.43 & 0.61 \\
\hline Low-Li-11 & CCC & Measured & 0.88 & 1.00 & 1.32 & 0.62 \\
\hline Low-Li-12 & $\overline{\mathrm{CCC}}$ & Measured & 0.84 & 0.85 & 1.27 & 0.57 \\
\hline Low-Li-13 & CCC & Measured & 0.78 & 0.68 & 1.21 & 0.53 \\
\hline Low-Li-14 & CCC & Measured & 0.80 & - & 1.28 & 0.55 \\
\hline
\end{tabular}

8 Note that for those glasses based on $0 \% \mathrm{Li}_{2} \mathrm{O}$ frits, a “-“ is shown in the NL [Li] g/L column. 


\subsection{Quenched Versus CCC}

Although not a specific programmatic objective, an assessment of whether or not the thermal heat treatment had an impact on the measured durability response for each glass composition is of interest. Figure 7-3 shows plots of the PCT response of quenched versus ccc glasses in terms of boron (in ppm) release. If the thermal heat treatment had no impact on the measured PCT response for a given glass, their corresponding values would lie directly on the $45^{\circ}$ line (shown in Figure 7-3 as a gray line). The $\log [\mathrm{B}]$ plot suggests that, in general, the quenched version of each glass has a lower durability (higher NL [B]) than their counterpart ccc version. The response of Low-Li-2 is of particular interest; the quenched version has a NL [B] of 0.87 while the ccc version has a release of 0.59 . This comparison is statistically significant, but implications in terms of practicality are of little concern.

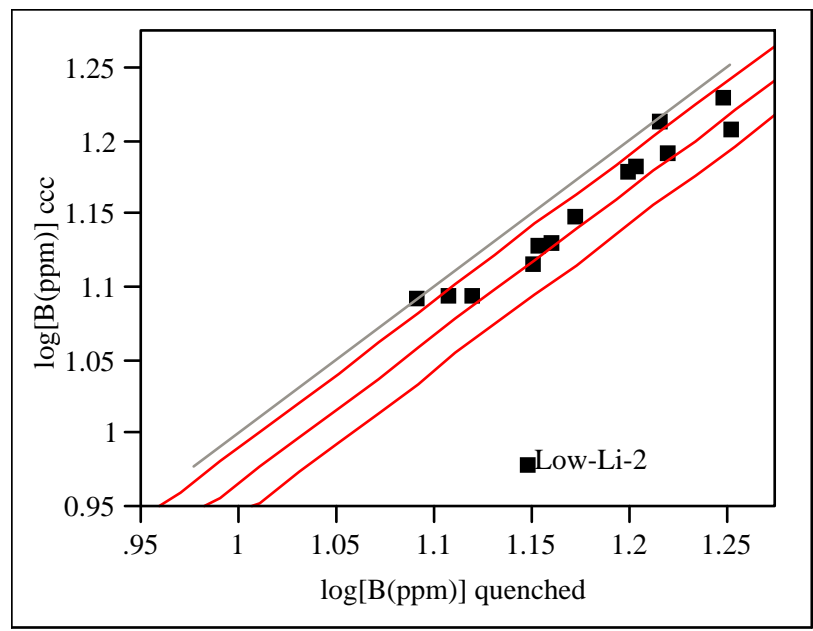

Figure 7-3. Quenched Versus ccc log [B (ppm)] (based on target compositions). 
WSRC-TR-2005-00306

Revision 0

\subsection{Predictability of the Durability Model}

Although acceptability of the glasses in terms of the normalized PCT response as they compare to the EA glass is a critical measure, predictability or applicability of the model is also an issue that should be addressed. The DWPF models relate the logarithm of the normalized PCT (for each element of interest) to a linear function of a free energy of hydration term ( $\Delta \mathrm{G}_{\mathrm{p}}$, kcal/100g glass) derived as a function of glass compositional view (Jantzen et al. 1995). If the measured PCT response of the study glasses falls within the prediction limits, at a $95 \%$ confidence for an individual PCT result, the model is deemed applicable to the compositional space being assessed. Figure 7-4 shows a plot of $\log \mathrm{NL}[\mathrm{B}]$ versus $\Delta \mathrm{G}_{\mathrm{p}}$ for the study glasses. The EA (open box in top left corner) and ARM (open box in bottom right hand portion) results are also indicated on these plots. Note that most of the study glasses fall outside the lower $95 \%$ confidence band. This suggests that the model is overly conservative with respect to its durability prediction based on composition alone by overestimating the anticipated PCT response. As discussed in the previous section, the experimental results do suggest that even the "proposed" durability limits can potentially limit access to compositional regions that may be of interest to either improve melt rate or waste loading for DWPF. One interesting fact is that there are study glasses with predicted $\Delta \mathrm{G}_{\mathrm{P}}$ values more negative than that of EA but the measured responses are very acceptable - this is consistent with observations made by Cozzi et al. (2003).

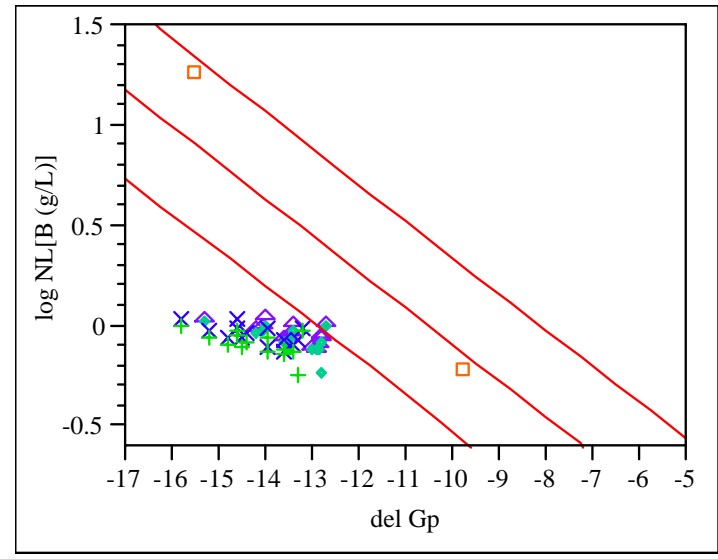

\footnotetext{
$\mathrm{Comp} / \mathrm{HT}$

- 1

+ Measured/ccc

x Measured/quenched

口 reference/

- target/ccc

$\triangle$ target/quenched
}

Figure 7-4. $\log \mathrm{NL}[\mathrm{B}]$ Versus $\Delta \mathrm{G}_{\mathrm{P}}$. 


\subsection{SUMMARY}

During the progressive development of the cold cap model (as it applies to a potential melt rate predictive tool), the formation of an Al-Li-silicate phase was identified as an intermediate reaction phase that could possibly hinder melt rate for SB4. To test this theory, six glasses were designed (using Frit 320's composition as the baseline) to maintain a constant $20 \mathrm{wt} \%$ sum of alkali content (in frit) by varying $\mathrm{Na}_{2} \mathrm{O}$ to $\mathrm{Li}_{2} \mathrm{O}$ ratios. The $\mathrm{Li}_{2} \mathrm{O}$ concentration ranged from 8 wt $\%$ down to $0 \%$ in either $2 \%$ or $1 \%$ increments with the differences being accounted for by an increase in $\mathrm{Na}_{2} \mathrm{O}$ concentration. Although the primary objective of the "lower $\mathrm{Li}_{2} \mathrm{O}$ " frits was to evaluate the potential for melt rate improvements, assessments of durability (as measured by the Product Consistency Test (PCT)) were also performed. The results suggest that durable glasses can be produced with these "lower $\mathrm{Li}_{2} \mathrm{O}$ " frits should it be necessary to pursue this option for improving melt rate.

In addition to the series of glasses to support melt rate assessments, a series of frits were also developed to challenge the current durability model based on the limits proposed by Edwards et al. (2004). Although the "new" limits allow access into compositional regions of interest (i.e., higher alkali systems) which can improve melt rate and/or waste loading, there may still be "additional" conservatism. In this report, two series of glasses were developed to challenge the "new" durability limits for the SB4 system. In the first series, the total alkali of the Frit 320based glasses (designed to support the melt rate program) was increased from $20 \mathrm{wt} \%$ to $21 \mathrm{wt} \%$ (in the frit), but the series also evaluated the possible impact of various $\mathrm{Na}_{2} \mathrm{O}$ and $\mathrm{Li}_{2} \mathrm{O}$ mass ratio differences. The second series pushed the alkali limit in the frit even further with frits containing either 22 or $24 \mathrm{wt} \%$ total alkali as well as various $\mathrm{Na}_{2} \mathrm{O}$ and $\mathrm{Li}_{2} \mathrm{O}$ mass ratios.

The results of the PCT evaluation indicated that all of the study glasses were acceptable as defined by their NL [B]'s as compared to the EA glass (with a $16.695 \mathrm{~g} / \mathrm{L} \mathrm{NL}$ [B]) - regardless of the compositional view (measured or target) or thermal heat treatment (quenched versus centerline canister cooled). The most durable glass (Low-Li-2 ccc) had a NL [B] of $0.59 \mathrm{~g} / \mathrm{L}$. This glass was part of the series supporting melt rate assessment. The least durable glass (based on NL [B] and target compositions) was Low-Li-7 (quenched) with a NL [B] of $1.11 \mathrm{~g} / \mathrm{L}$. Given the higher concentration of alkali (a glass within the " $22-24$ wt\% total alkali" series), it is not surprising that the least durable glass comes out of this grouping. However, the $1.11 \mathrm{~g} / \mathrm{L}$ is well below the benchmark of $16.695 \mathrm{~g} / \mathrm{L}$ for the EA glass. With the measured PCT responses being acceptable (i.e., all $<1.11 \mathrm{~g} / \mathrm{L}$ ) the results suggest additional conservatism exists within the current durability model even with the "proposed" limits. More specifically, the "proposed" limits still appear to restrict access to compositional regions of interest (higher alkali glasses) even though their measured PCT responses are acceptable.

Although acceptability of the glasses in terms of the normalized PCT response as they compare to the EA glass is a critical measure, predictability or applicability of the model was also addressed. The results indicated that most of the study glasses fall outside the lower 95\% confidence band which suggests that the model is overly conservative with respect to its durability prediction based on composition alone by overestimating the anticipated PCT response. If "low $\mathrm{Li}_{2} \mathrm{O}$ " frits are advantageous to melt rate, the data presented in this report suggest that the resulting glasses (based on the specific frits assessed) are durable (as defined by the PCT. 


\subsection{RECOMMENDATIONS}

Based on the results of this study, the following recommendations are made:

(1) The results of this study indicate that additional conservatism still exists within the durability model even with the "proposed" (less restrictive) durability limits. This being the case, efforts to identify and/or implement alternative durability approaches are warranted assuming those efforts provide incentive for DWPF. Incentive could take the form of allowing access into compositional regions of interest to improve waste loading and/or melt rate for future sludge batches.

(2) Assessments of melt rate should be made with the "low $\mathrm{Li}_{2} \mathrm{O}$ " frits to support melt rate modeling efforts. These data could be used to adjust (if warranted) the melt rate indicator currently being used to rank various flowsheets in terms of melt rate. It should be noted that if SB4 is used for this assessment, it is possible that the high $\mathrm{Al}_{2} \mathrm{O}_{3}$ content may dictate the melt rate and thus a "true" assessment of the impact of lower $\mathrm{Li}_{2} \mathrm{O}$ frits may not be realized. 
WSRC-TR-2005-00306

Revision 0

\subsection{REFERENCES}

ASTM 2002. Standard Test Methods for Determining Chemical Durability of Nuclear Waste Glasses: The Product Consistency Test (PCT), ASTM C-1285-2002.

Brown KG, CM Jantzen, and G Ritzhaupt. 2001. Relating Liquidus Temperature to Composition for Defense Waste Processing Facility (DWPF) Process Control, WSRC-TR-2001-00520, Westinghouse Savannah River Company, Aiken, South Carolina.

Brown, KG, RL Postles, and TB Edwards. 2002. SME Acceptability Determination for DWPF Process Control, WSRC-TR-95-0364, Revision 4, Westinghouse Savannah River Company, Aiken, South Carolina.

Choi, AS, DK Peeler, and TB Edwards. 2005. Modeling of Melt Rate for DWPF: A Preliminary Assessment, to be published in the Proceedings of the $107^{\text {th }}$ Annual American Ceramic Society Meeting, Baltimore, Maryland.

Choi, AS. 2000. Validation of DWPF Melter Off-Gas Combustion Model, WSRC-TR-200000100, Revision 0, Westinghouse Savannah River Company, Aiken, South Carolina.

Cozzi, AD, TB Edwards, and DK Peeler. 2003. Durability Assessments of High Alkali Glasses in Support of the Accelerated Clean-Up Mission: Experimental Results of the "ND" Glasses, WSRC-TR-2003-00287, Revision 0, Westinghouse Savannah River Company, Aiken, South Carolina.

Edwards, TB, and KG Brown. 1998. Evaluating the Glasses Batched for the Tank 42 Variability Study, SRT-SCS-98-017, Revision 0, Westinghouse Savannah River Company, Aiken, South Carolina.

Edwards, TB, DK Peeler, and SL Marra. 2004. Revisiting the Prediction Limits for Acceptable Durability, WSRC-TR-2003-00510, Revision 0, Westinghouse Savannah River Company, Aiken, South Carolina.

Elder, HH. 2005. Estimate of Sludge Batch 4 Calcine Composition, CBU-PIT-2005-00134, Westinghouse Savannah River Company, Aiken, South Carolina.

Jantzen CM, NE Bibler, DC Beam, CL Crawford, and MA Pickett. 1993. Characterization of the DWPF Environmental Assessment (EA) Glass Standard Reference Material (U), WSRC-TR-92346, Revision 1, Westinghouse Savannah River Company, Aiken, South Carolina.

Jantzen, CM, JB Pickett, KG Brown, TB Edwards, and DC Beam. 1995. Process/Product Models for the Defense Waste Processing Facility (DWPF): Part I. Predicting Glass Durability from Composition Using a Thermodynamic Hydration Energy Reaction Model (THERMO), WSRC-TR-93-672, Revision 1, Volume 1, Westinghouse Savannah River Company, Aiken, South Carolina.

Lilliston, GR. 2005. Development of Elemental Sludge Compositions for Variations of Sludge Batch 4 (SB4), CBU-PIT-2004-00022, Westinghouse Savannah River Company, Aiken, South Carolina. 
Lorier, TH, TM Jones, and DC Witt. 2002. Melt Rate Testing for the DWPF: Summary of FY02 Testing, WSRC-TR-2002-00545, Revision 0, Westinghouse Savannah River Company, Aiken, South Carolina.

Lorier, TH and ME Smith. 2004. Melt Rate Assessment of SB2/3 with Frit 418 - Effects of Waste Loading and Acid Addition, WSRC-TR-2004-00098, Westinghouse Savannah River Company, Aiken, South Carolina.

Marra SL and CM Jantzen. 1993. Characterization of Projected DWPF Glass Heat Treated to Simulate Canister Centerline Cooling, WSRC-TR-92-142, Revision 1, Westinghouse Savannah River Company, Aiken, South Carolina.

Peeler, DK, TH Lorier, DF Bickford, DC Witt, TB Edwards, KG Brown, IA Reamer, RJ Workman, and JD Vienna. 2001. Melt Rate Improvement for DWPF MB3: Frit Development and Model Assessment, WSRC-TR-2001-00131, Revision 0, Westinghouse Savannah River Company, Aiken, South Carolina.

Peeler, DK and TB Edwards. 2002. Frit Development for Sludge Batch 3, WSRC-TR-200200491, Revision 0, Westinghouse Savannah River Company, Aiken, South Carolina.

Peeler, DK, TB Edwards, and AS Taylor. 2004a. The Impact of the Proposed $\Delta G_{P}$ Limits on Glass Formulation Efforts: Part I. Model-Based Assessments, WSRC-TR-2004-00203, Revision 0, Westinghouse Savannah River Company, Aiken, South Carolina.

Peeler, DK, TB Edwards, and AS Taylor. 2004b. The Impact of the Proposed $\Delta G_{P}$ Limits on Glass Formulation Efforts: Part II. Experimental Results, WSRC-TR-2004-00348, Revision 0, Westinghouse Savannah River Company, Aiken, South Carolina.

Peeler, DK and TB Edwards, 2005. A Preliminary Assessment of the Need for a Sludge Batch 4 Variability Study, WSRC-TR-2005-00122, Westinghouse Savannah River Company, Aiken, South Carolina.

Savannah River National Laboratory. 2004a. “Glass Batching,” SRTC Procedure Manual, L29, ITS- 0001, Westinghouse Savannah River Company, Aiken, South Carolina.

Savannah River National Laboratory. 2004b. “Glass Melting,” SRTC Procedure Manual, L29, ITS-0003, Westinghouse Savannah River Company, Aiken, South Carolina.

Smith, M.E., T.H. Lorier and T.M. Jones. 2003. SMRF and MRF DWPF Melt Rate Testing for SB2/SB3 (Case 6B - 250 Canisters), WSRC-TR-2003-00466, Revision 0, Westinghouse Savannah River Company, Aiken, South Carolina.

Smith, ME, DH Miller, and TM Jones. 2004. Slurry-Fed Melt Rate Furnace Test for the SB3/Frit 320 Feed System, WSRC-TR-2004-00459, Revision 0, Westinghouse Savannah River Company, Aiken, South Carolina.

Stone, ME and JE Josephs. 2001. Melt Rate Improvements for DWPF MB3: Melt Rate Furnace Testing, WSRC-TR-2001-00146, Revision 0, Westinghouse Savannah River Company, Aiken, South Carolina. 
WSRC-TR-2005-00306

Revision 0

Waste Acceptance Product Specifications (WAPS). 1996. Office of Environmental

Management, Waste Acceptance Product Specifications for Vitrified High-Level Waste Forms,

Revision 2, USDOE Document EM-WAPS, U.S. Department of Energy, Germantown, Maryland. 
WSRC-TR-2005-00306

Revision 0

\section{Appendix A}

\section{Target Versus Measured Compositions and} \% Relative Difference 
Table A.1. Target Versus Measured Compositions of the " 20 wt\% total Alkali” Series.

\begin{tabular}{|c|c|c|c|c|c|c|c|c|c|c|c|c|c|c|c|c|c|c|}
\hline & \multicolumn{3}{|c|}{ Low-Li-1 } & \multicolumn{3}{|c|}{ Low-Li-2 } & \multicolumn{3}{|c|}{ Low-Li-3 } & \multicolumn{3}{|c|}{ Low-Li-4 } & \multicolumn{3}{|c|}{ Low-Li-5 } & \multicolumn{3}{|c|}{ Low-Li-6 } \\
\hline & \multicolumn{3}{|c|}{$320,35 \% \mathrm{WL}$} & \multicolumn{3}{|c|}{ 320f, 35\% WL } & \multicolumn{3}{|c|}{ 320g, 35\% WL } & \multicolumn{3}{|c|}{ 320h, 35\% WL } & \multicolumn{3}{|c|}{ 320i, 35\% WL } & \multicolumn{3}{|c|}{ 320r, 35\% WL } \\
\hline & Target & Meas & \% Diff & Target & Meas & \% Diff & Target & Meas & \% Diff & Target & Meas & \% Diff & Target & Meas & \% Diff & Target & Meas & \% Diff \\
\hline $\mathrm{Al}_{2} \mathrm{O}_{3}$ & 8.025 & 8.34 & 3.93 & 8.025 & 8.29 & 3.30 & 8.025 & 8.25 & 2.80 & 8.025 & 8.33 & 3.80 & 8.025 & 8.41 & 4.80 & 8.025 & 8.40 & 4.67 \\
\hline $\mathrm{B}_{2} \mathrm{O}_{3}$ & 5.200 & 5.60 & 7.69 & 5.200 & 5.40 & 3.85 & 5.200 & 5.43 & 4.42 & 5.200 & 5.47 & 5.19 & 5.200 & 5.41 & 4.04 & 5.200 & 5.59 & 7.50 \\
\hline $\mathrm{BaO}$ & 0.057 & 0.06 & 5.26 & 0.057 & 0.05 & -12.28 & 0.057 & 0.06 & 5.26 & 0.057 & 0.05 & -12.28 & 0.057 & 0.05 & -12.28 & 0.057 & 0.05 & -12.28 \\
\hline $\mathrm{CaO}$ & 0.790 & 0.79 & 0.00 & 0.790 & 0.80 & 1.27 & 0.790 & 0.79 & 0.00 & 0.790 & 0.76 & -3.80 & 0.790 & 0.77 & -2.53 & 0.790 & 0.78 & -1.27 \\
\hline $\mathrm{Ce}_{2} \mathrm{O}_{3}$ & 0.074 & NM & - & 0.074 & NM & - & 0.074 & NM & - & 0.074 & NM & - & 0.074 & NM & - & 0.074 & NM & \\
\hline $\mathrm{Cr}_{2} \mathrm{O}_{3}$ & 0.089 & 0.08 & -10.11 & 0.089 & 0.08 & -10.11 & 0.089 & 0.07 & -21.35 & 0.089 & 0.08 & -10.11 & 0.089 & 0.07 & -21.35 & 0.089 & 0.08 & -10.11 \\
\hline $\mathrm{CuO}$ & 0.030 & 0.04 & 33.33 & 0.030 & 0.04 & 33.33 & 0.030 & 0.04 & 33.33 & 0.030 & 0.04 & 33.33 & 0.030 & 0.04 & 33.33 & 0.030 & 0.04 & 33.33 \\
\hline $\mathrm{Fe}_{2} \mathrm{O}_{3}$ & 9.204 & 9.42 & 2.35 & 9.204 & 9.17 & -0.37 & 9.204 & 9.15 & -0.59 & 9.204 & 9.00 & -2.22 & 9.204 & 8.92 & -3.09 & 9.204 & 9.33 & 1.37 \\
\hline $\mathrm{K}_{2} \mathrm{O}$ & 0.363 & 0.41 & 12.95 & 0.363 & 0.41 & 12.95 & 0.363 & 0.41 & 12.95 & 0.363 & 0.44 & 21.21 & 0.363 & 0.45 & 23.97 & 0.363 & 0.44 & 21.21 \\
\hline $\mathrm{La}_{2} \mathrm{O}_{3}$ & 0.033 & 0.03 & -9.09 & 0.033 & 0.03 & -9.09 & 0.033 & 0.03 & -9.09 & 0.033 & 0.03 & -9.09 & 0.033 & 0.03 & -9.09 & 0.033 & 0.03 & -9.09 \\
\hline $\mathrm{Li}_{2} \mathrm{O}$ & 5.200 & 5.21 & 0.19 & 3.900 & 3.94 & 1.03 & 2.600 & 2.70 & 3.85 & 1.300 & 1.47 & 13.08 & 0.000 & $<1.0$ & - & 3.250 & 3.37 & 3.69 \\
\hline $\mathrm{MgO}$ & 0.687 & 0.69 & 0.44 & 0.687 & 0.67 & -2.47 & 0.687 & 0.68 & -1.02 & 0.687 & 0.65 & -5.39 & 0.687 & 0.64 & -6.84 & 0.687 & 0.66 & -3.93 \\
\hline $\mathrm{MnO}$ & 2.066 & 2.70 & 30.69 & 2.066 & 2.65 & 28.27 & 2.066 & 2.67 & 29.24 & 2.066 & 2.67 & 29.24 & 2.066 & 2.72 & 31.66 & 2.066 & 2.71 & 31.17 \\
\hline $\mathrm{Na}_{2} \mathrm{O}$ & 15.595 & 16.02 & 2.73 & 16.895 & 17.34 & 2.63 & 18.195 & 18.61 & 2.28 & 19.495 & 19.99 & 2.54 & 20.795 & 21.83 & 4.98 & 17.545 & 18.27 & 4.13 \\
\hline $\mathrm{NiO}$ & 1.315 & 1.23 & -6.46 & 1.315 & 1.23 & -6.46 & 1.315 & 1.28 & -2.66 & 1.315 & 1.26 & -4.18 & 1.315 & 1.23 & -6.46 & 1.315 & 1.23 & -6.46 \\
\hline $\mathrm{PbO}$ & 0.059 & 0.06 & 1.69 & 0.059 & 0.06 & 1.69 & 0.059 & 0.06 & 1.69 & 0.059 & 0.05 & -15.25 & 0.059 & 0.06 & 1.69 & 0.059 & 0.05 & -15.25 \\
\hline $\mathrm{SiO}_{2}$ & 47.767 & 48.12 & 0.74 & 47.767 & 48.07 & 0.63 & 47.767 & 48.10 & 0.70 & 47.767 & 48.15 & 0.80 & 47.767 & 48.20 & 0.91 & 47.767 & 48.69 & 1.93 \\
\hline $\mathrm{ThO}_{2}$ & 0.012 & $<0.114$ & & 0.012 & $<0.114$ & - & 0.012 & $<0.114$ & - & 0.012 & $<0.114$ & - & 0.012 & $<0.114$ & - & 0.012 & $<0.114$ & \\
\hline $\mathrm{TiO}_{2}$ & 0.008 & 0.01 & 25.00 & 0.008 & 0.01 & 25.00 & 0.008 & 0.01 & 25.00 & 0.008 & 0.01 & 25.00 & 0.008 & 0.01 & 25.00 & 0.008 & 0.01 & 25.00 \\
\hline $\mathrm{U}_{3} \mathrm{O}_{8}$ & 3.283 & 2.91 & -11.36 & 3.283 & 2.83 & -13.80 & 3.283 & 2.92 & -11.06 & 3.283 & 2.71 & -17.45 & 3.283 & 2.66 & -18.98 & 3.283 & 2.60 & -20.80 \\
\hline $\mathrm{ZnO}$ & 0.045 & 0.05 & 11.11 & 0.045 & 0.05 & 11.11 & 0.045 & 0.05 & 11.11 & 0.045 & 0.05 & 11.11 & 0.045 & 0.05 & 11.11 & 0.045 & 0.05 & 11.11 \\
\hline $\mathrm{ZrO}_{2}$ & 0.099 & 0.08 & -19.19 & 0.099 & 0.09 & -9.09 & 0.099 & 0.09 & -9.09 & 0.099 & 0.09 & -9.09 & 0.099 & 0.08 & -19.19 & 0.099 & 0.09 & -9.09 \\
\hline Sum & 100.00 & 101.85 & & 100.00 & 101.22 & & 100.00 & 101.39 & & 100.00 & 101.28 & & 100.00 & 101.65 & & 100.00 & 102.45 & \\
\hline
\end{tabular}


Table A.2. Target Versus Measured Compositions of the "21 wt\% total Alkali" Series.

\begin{tabular}{|c|c|c|c|c|c|c|c|c|c|c|c|}
\hline & \multicolumn{3}{|c|}{ Low-Li-7 } & \multicolumn{3}{|c|}{ Low-Li-8 } & \multicolumn{3}{|c|}{ Low-Li-9 } & \multicolumn{2}{|c|}{ Low-Li-10 } \\
\hline & \multicolumn{3}{|c|}{ 320j, 35\% WL } & \multicolumn{3}{|c|}{$320 \mathrm{k}, 35 \% \mathrm{WL}$} & \multicolumn{3}{|c|}{ 320l, 35\% WL } & \multicolumn{2}{|c|}{$320 \mathrm{~m}, 35 \% \mathrm{WL}$} \\
\hline & Target & Measured & \% Diff & Target & Measured & \% Diff & Target & $\begin{array}{c}\text { Measure } \\
\text { d }\end{array}$ & \% Diff & Target & Measured \\
\hline $\mathrm{Al}_{2} \mathrm{O}_{3}$ & 8.025 & 8.20 & 2.18 & 8.025 & 8.29 & 3.30 & 8.025 & 8.19 & 2.06 & 8.025 & 8.35 \\
\hline $\mathrm{B}_{2} \mathrm{O}_{3}$ & 5.200 & 5.46 & 5.00 & 5.200 & 5.42 & 4.23 & 5.200 & 5.47 & 5.19 & 5.200 & 5.50 \\
\hline $\mathrm{BaO}$ & 0.057 & 0.05 & -12.28 & 0.057 & 0.05 & -12.28 & 0.057 & 0.05 & -12.28 & 0.057 & 0.05 \\
\hline $\mathrm{CaO}$ & 0.790 & 0.75 & -5.06 & 0.790 & 0.75 & -5.06 & 0.790 & 0.75 & -5.06 & 0.790 & 0.77 \\
\hline $\mathrm{Ce}_{2} \mathrm{O}_{3}$ & 0.074 & NM & - & 0.074 & NM & - & 0.074 & NM & - & 0.074 & NM \\
\hline $\mathrm{Cr}_{2} \mathrm{O}_{3}$ & 0.089 & 0.08 & -10.11 & 0.089 & 0.08 & -10.11 & 0.089 & 0.08 & -10.11 & 0.089 & 0.08 \\
\hline $\mathrm{CuO}$ & 0.030 & 0.04 & 33.33 & 0.030 & 0.04 & 33.33 & 0.030 & 0.04 & 33.33 & 0.030 & 0.04 \\
\hline $\mathrm{Fe}_{2} \mathrm{O}_{3}$ & 9.204 & 9.30 & 1.04 & 9.204 & 9.31 & 1.15 & 9.204 & 9.16 & -0.48 & 9.204 & 9.08 \\
\hline $\mathrm{K}_{2} \mathrm{O}$ & 0.363 & 0.44 & 21.21 & 0.363 & 0.46 & 26.72 & 0.363 & 0.43 & 18.46 & 0.363 & 0.44 \\
\hline $\mathrm{La}_{2} \mathrm{O}_{3}$ & 0.033 & 0.03 & -9.09 & 0.033 & 0.03 & -9.09 & 0.033 & 0.03 & -9.09 & 0.033 & 0.03 \\
\hline $\mathrm{Li}_{2} \mathrm{O}$ & 3.900 & 3.92 & 0.51 & 2.600 & 2.66 & 2.31 & 1.300 & 1.44 & 10.77 & 0.000 & $<1.0$ \\
\hline $\mathrm{MgO}$ & 0.687 & 0.64 & -6.84 & 0.687 & 0.64 & -6.84 & 0.687 & 0.66 & -3.93 & 0.687 & 0.64 \\
\hline $\mathrm{MnO}$ & 2.066 & 2.66 & 28.75 & 2.066 & 2.69 & 30.20 & 2.066 & 2.64 & 27.78 & 2.066 & 2.73 \\
\hline $\mathrm{Na}_{2} \mathrm{O}$ & 18.195 & 18.78 & 3.22 & 19.495 & 19.98 & 2.49 & 22.095 & 22.38 & 1.29 & 22.095 & 23.17 \\
\hline $\mathrm{NiO}$ & 1.315 & 1.26 & -4.18 & 1.315 & 1.27 & -3.42 & 1.315 & 1.25 & -4.94 & 1.315 & 1.24 \\
\hline $\mathrm{PbO}$ & 0.059 & 0.05 & -15.25 & 0.059 & 0.05 & -15.25 & 0.059 & 0.05 & -15.25 & 0.059 & 0.05 \\
\hline $\mathrm{SiO}_{2}$ & 46.467 & 47.32 & 1.84 & 46.467 & 47.29 & 1.77 & 45.167 & 45.44 & 0.60 & 46.467 & 46.99 \\
\hline $\mathrm{ThO}_{2}$ & 0.012 & $<0.114$ & - & 0.012 & $<0.114$ & - & 0.012 & $<0.114$ & - & 0.012 & $<0.114$ \\
\hline $\mathrm{TiO}_{2}$ & 0.008 & 0.01 & 25.00 & 0.008 & 0.01 & 25.00 & 0.008 & 0.01 & 25.00 & 0.008 & 0.01 \\
\hline $\mathrm{U}_{3} \mathrm{O}_{8}$ & 3.283 & 2.74 & -16.54 & 3.283 & 2.71 & -17.45 & 3.283 & 2.66 & -18.98 & 3.283 & 2.83 \\
\hline $\mathrm{ZnO}$ & 0.045 & 0.04 & -11.11 & 0.045 & 0.04 & -11.11 & 0.045 & 0.05 & 11.11 & 0.045 & 0.05 \\
\hline $\mathrm{ZrO}_{2}$ & 0.099 & 0.07 & -29.29 & 0.099 & 0.08 & -19.19 & 0.099 & 0.09 & -9.09 & 0.099 & 0.09 \\
\hline Sum & 100.00 & 101.86 & & 100.00 & 101.85 & & 100.00 & 100.85 & & 100.00 & 102.13 \\
\hline
\end{tabular}


Table A.3. Target Versus Measured Compositions of the " 22 and 24 wt \% total Alkali" Series.

\begin{tabular}{|c|c|c|c|c|c|c|c|c|c|c|c|c|}
\hline & \multicolumn{3}{|c|}{ Low-Li-11 } & \multicolumn{3}{|c|}{ "Low-Li-12 } & \multicolumn{3}{|c|}{ "Low-Li-13 } & \multicolumn{3}{|c|}{ Low-Li-14 } \\
\hline & \multicolumn{3}{|c|}{ 320n, 35\% WL } & \multicolumn{3}{|c|}{ 320o, 35\% WL } & \multicolumn{3}{|c|}{ 320p, 35\% WL } & \multicolumn{3}{|c|}{ 320q, 35\% WL } \\
\hline & Target & Measured & \% Diff & Target & Measured & \% Diff & Target & $\begin{array}{c}\text { Measure } \\
\mathrm{d}\end{array}$ & \% Diff & Target & $\begin{array}{c}\text { Measure } \\
\mathrm{d}\end{array}$ & \% Diff \\
\hline $\mathrm{Al}_{2} \mathrm{O}_{3}$ & 8.025 & 8.20 & 2.18 & 8.025 & 8.43 & 5.05 & 8.025 & 8.39 & 4.55 & 8.025 & 8.40 & 4.67 \\
\hline $\mathrm{B}_{2} \mathrm{O}_{3}$ & 5.200 & 5.65 & 8.65 & 5.200 & 5.40 & 3.85 & 5.200 & 5.39 & 3.65 & 5.200 & 5.38 & 3.46 \\
\hline $\mathrm{BaO}$ & 0.057 & 0.05 & -12.28 & 0.057 & 0.05 & -12.28 & 0.057 & 0.05 & -12.28 & 0.057 & 0.05 & -12.28 \\
\hline $\mathrm{CaO}$ & 0.790 & 0.75 & -5.06 & 0.790 & 0.77 & -2.53 & 0.790 & 0.75 & -5.06 & 0.790 & 0.75 & -5.06 \\
\hline $\mathrm{Ce}_{2} \mathrm{O}_{3}$ & 0.074 & NM & - & 0.074 & NM & - & 0.074 & NM & - & 0.074 & NM & - \\
\hline $\mathrm{Cr}_{2} \mathrm{O}_{3}$ & 0.089 & 0.08 & -10.11 & 0.089 & 0.08 & -10.11 & 0.089 & 0.08 & -10.11 & 0.089 & 0.07 & -21.35 \\
\hline $\mathrm{CuO}$ & 0.030 & 0.04 & 33.33 & 0.030 & 0.04 & 33.33 & 0.030 & 0.04 & 33.33 & 0.030 & 0.04 & 33.33 \\
\hline $\mathrm{Fe}_{2} \mathrm{O}_{3}$ & 9.204 & 9.28 & 0.83 & 9.204 & 9.40 & 2.13 & 9.204 & 9.09 & -1.24 & 9.204 & 9.05 & -1.67 \\
\hline $\mathrm{K}_{2} \mathrm{O}$ & 0.363 & 0.43 & 18.46 & 0.363 & 0.44 & 21.21 & 0.363 & 0.44 & 21.21 & 0.363 & 0.45 & 23.97 \\
\hline $\mathrm{La}_{2} \mathrm{O}_{3}$ & 0.033 & 0.03 & -9.09 & 0.033 & 0.03 & -9.09 & 0.033 & 0.03 & -9.09 & 0.033 & 0.03 & -9.09 \\
\hline $\mathrm{Li}_{2} \mathrm{O}$ & 3.900 & 3.96 & 1.54 & 2.600 & 2.73 & 5.00 & 1.300 & 1.46 & 12.31 & 0.000 & $<1.0$ & - \\
\hline $\mathrm{MgO}$ & 0.687 & 0.65 & -5.39 & 0.687 & 0.66 & -3.93 & 0.687 & 0.64 & -6.84 & 0.687 & 0.64 & -6.84 \\
\hline $\mathrm{MnO}$ & 2.066 & 2.70 & 30.69 & 2.066 & 2.76 & 33.59 & 2.066 & 2.72 & 31.66 & 2.066 & 2.75 & 33.11 \\
\hline $\mathrm{Na}_{2} \mathrm{O}$ & 17.545 & 17.98 & 2.48 & 18.845 & 19.88 & 5.49 & 20.145 & 21.10 & 4.74 & 21.445 & 22.78 & 6.23 \\
\hline $\mathrm{NiO}$ & 1.315 & 1.29 & -1.90 & 1.315 & 1.21 & -7.98 & 1.315 & 1.23 & -6.46 & 1.315 & 1.19 & -9.51 \\
\hline $\mathrm{PbO}$ & 0.059 & 0.05 & -15.25 & 0.059 & 0.05 & -15.25 & 0.059 & 0.05 & -15.25 & 0.059 & 0.05 & -15.25 \\
\hline $\mathrm{SiO}_{2}$ & 47.117 & 47.27 & 0.32 & 47.117 & 48.50 & 2.94 & 47.117 & 48.15 & 2.19 & 47.117 & 47.96 & 1.79 \\
\hline $\mathrm{ThO}_{2}$ & 0.012 & $<0.114$ & & 0.012 & $<0.114$ & - & 0.012 & $<0.114$ & & 0.012 & $<0.114$ & - \\
\hline $\mathrm{TiO}_{2}$ & 0.008 & 0.01 & 25.00 & 0.008 & 0.01 & 25.00 & 0.008 & 0.01 & 25.00 & 0.008 & 0.01 & 25.00 \\
\hline $\mathrm{U}_{3} \mathrm{O}_{8}$ & 3.283 & 2.80 & -14.71 & 3.283 & 2.62 & -20.19 & 3.283 & 2.71 & -17.45 & 3.283 & 2.60 & -20.80 \\
\hline $\mathrm{ZnO}$ & 0.045 & 0.05 & 11.11 & 0.045 & 0.05 & 11.11 & 0.045 & 0.04 & -11.11 & 0.045 & 0.05 & 11.11 \\
\hline $\mathrm{ZrO}_{2}$ & 0.099 & 0.08 & -19.19 & 0.099 & 0.09 & -9.09 & 0.099 & 0.08 & -19.19 & 0.099 & 0.09 & -9.09 \\
\hline Sum & 100.00 & 101.37 & & 100.00 & 103.21 & & 100.00 & 102.47 & & 100.00 & 102.32 & \\
\hline
\end{tabular}


Table A.4 Target Versus Measured and \% Relative Difference on the Batch 1 Standard Glass.

\begin{tabular}{|c|c|c|c|}
\hline & \multicolumn{3}{|c|}{ Batch 1 Std } \\
\hline & Target & $\begin{array}{c}\text { Measure } \\
\mathrm{d}\end{array}$ & \% Diff \\
\hline $\mathrm{Al}_{2} \mathrm{O}_{3}$ & 4.877 & 4.83 & -0.964 \\
\hline $\mathrm{B}_{2} \mathrm{O}_{3}$ & 7.777 & 8.44 & 8.525 \\
\hline $\mathrm{BaO}$ & 0.151 & 0.14 & -10.596 \\
\hline $\mathrm{CaO}$ & 1.22 & 1.13 & $\begin{array}{l}-7.377 \\
\end{array}$ \\
\hline $\mathrm{Ce}_{2} \mathrm{O}_{3}$ & 0 & NM & - \\
\hline $\mathrm{Cr}_{2} \mathrm{O}_{3}$ & 0.107 & 0.09 & -16.822 \\
\hline $\mathrm{CuO}$ & 0.399 & 0.36 & $\begin{array}{l}-10.526 \\
\end{array}$ \\
\hline $\mathrm{Fe}_{2} \mathrm{O}_{3}$ & 12.839 & 12.60 & -1.862 \\
\hline $\mathrm{K}_{2} \mathrm{O}$ & 3.327 & 3.55 & 6.703 \\
\hline $\mathrm{La}_{2} \mathrm{O}_{3}$ & 0 & $<.01$ & - \\
\hline $\mathrm{Li}_{2} \mathrm{O}$ & 4.429 & 4.48 & 1.152 \\
\hline $\mathrm{MgO}$ & 1.419 & 1.28 & -9.796 \\
\hline $\mathrm{MnO}$ & 1.726 & 2.13 & 23.407 \\
\hline $\mathrm{Na}_{2} \mathrm{O}$ & 9.003 & 9.34 & 3.743 \\
\hline $\mathrm{NiO}$ & 0.751 & 0.72 & -4.394 \\
\hline $\mathrm{PbO}$ & 0 & 0.00 & - \\
\hline $\mathrm{SiO}_{2}$ & 50.22 & 51.00 & 1.553 \\
\hline $\mathrm{ThO}_{2}$ & 0 & $<0.114$ & - \\
\hline $\mathrm{TiO}_{2}$ & 0.677 & 0.60 & -11.521 \\
\hline $\mathrm{U}_{3} \mathrm{O}_{8}$ & 0 & $<0.118$ & - \\
\hline $\mathrm{ZnO}$ & 0 & 0.00 & - \\
\hline $\mathrm{ZrO}_{2}$ & 0.098 & 0.08 & $\begin{array}{l}-17.347 \\
\end{array}$ \\
\hline
\end{tabular}


WSRC-TR-2005-00306

Revision 0

\begin{tabular}{||l|l|l|l||}
\hline & & & \\
\hline Total & 99.02 & 101.00 & \\
\hline
\end{tabular}




\section{Distribution:}

E. W. Holtzscheiter, 773-A

R.C. Tuckfield, 773-42A

S. L. Marra, 999-W

D. K. Peeler, 999-W

T. B. Edwards, 773-42A

C. C. Herman, 773-42A

M.E. Smith, 999-W 